Materiales de Construcción

Vol. 66, Issue 323, July-September 2016, e093

ISSN-L: 0465-2746

http://dx.doi.org/10.3989/mc.2016.03915

\title{
The exploitation of sludge from aggregate plants in the manufacture of porous fired clay bricks
}

\author{
M. A. Chamorro-Trenado $₫$, M. M. Pareta-Marjanedas ${ }^{\mathrm{a}}$, \\ B. E. Berthelsen-Molist ${ }^{\mathrm{b}}$, F. X. Janer-Adrian ${ }^{\mathrm{b}}$ \\ a. Department of Architecture and Building Engineering. CATS Research Group \\ (Construction, Advanced Technologies and Sustainability). Higher Polytechnic \\ School of the University of Girona (Girona, Spain) \\ b. CATS Research Group (Construction, Advanced Technologies and Sustainability). \\ TERRAM Association. (Girona, Spain) \\ \mangel.chamorro@udg.edu
}

Received 15 May 2015

Accepted 3 February 2016

Available on line 21 July 2016

\begin{abstract}
Aggregates (gravel and sand) are, after water, the Earth's second most used natural resource, representing about $50 \%$ of all consumed mineral resources. Aggregate production generates a large quantity of waste from the aggregate washing process. This waste is made up of suspended solids - sludge - which has a great environmental impact. It is deposited in huge troughs because of the impossibility of discharging it directly into rivers. Many plants have incorporated decanters and filter presses to separate the solid from the liquid fraction. This paper evaluates the possibility of exploiting the solid fraction (i.e. sludge) in the manufacture of fired clay bricks. The added value of these bricks is, on the one hand, the exploitation of sludge as a currently useless waste product, and on the other, the use of this sludge to enhance the physical and mechanical properties of conventional fired clay bricks.
\end{abstract}

KEYWORDS: Brick; Ceramic; Waste treatment; Physical properties; Mechanical properties

Citation/Citar como: Chamorro-Trenado, M.A.; Pareta-Marjanedas, M.M.; Berthelsen-Molist, B.E.; Janer-Adrian, F.X. (2016) The exploitation of sludge from aggregate plants in the manufacture of porous fired clay bricks. Mater. Construcc. 66 [323], e093 http://dx.doi.org/10.3989/mc.2016.03915

RESUMEN: Aprovechamiento de barros procedentes de central de áridos para la elaboración de piezas cerámicas porosas. Los áridos son la segunda materia prima más consumida en la Tierra después del agua, representando alrededor del 50\% de todos los recursos minerales consumidos. El proceso de elaboración de estos áridos genera una gran cantidad de residuos procedentes de su lavado. Se trata de partículas sólidas en suspensión - lodos - de gran impacto ambiental, que se depositan en grandes charcas ante la imposibilidad de verterlos directamente al rio. Muchas empresas han incorporado decantadores y filtros de prensa para separar la fracción solida de la líquida. El presente trabajo evalúa la posibilidad de utilizar la fracción sólida, es decir el barro, para la fabricación de piezas cerámicas. El valor añadido de estas piezas es por un lado el aprovechamiento del barro como producto residual, que en estos momentos es desechable, y por otro, conseguir que este barro mejore las propiedades físico-mecánicas de la cerámica convencional.

PALABRAS CLAVE: Ladrillo; Cerámica; Tratamiento residuos; Propiedades físicas; Propiedades mecánicas

Copyright: (C) 2016 CSIC. This is an open-access article distributed under the terms of the Creative Commons Attribution License (CC BY) Spain 3.0. 


\section{INTRODUCTION}

In the last two decades, a great deal of research has been done to encourage the reuse of waste. In 1997, Dondi et al. $(1,2)$ presented a two-part review on the recycling of industrial urban waste into fired clay for brick production. The authors classified the wastes into 4 main categories: fuel waste, fly-ash, fluxing, plasticity-reducing and plastifying waste. Included in the first group was waste from sewage sludge treatment plants, paper industry sludge, sawdust, waste from the textile industry, tanning industry waste, coal mining waste, petroleum refinery waste and others; included in the second group was fly-ash - unburned very fine carbonaceous particles $(5-200 \mu \mathrm{m})$ generated during the combustion of coal as a fuel in thermal plants -;the third group included silica-alumina waste with an extremely variable content of heavy metals and alkaline elements coming from the glazing lines of fired clay tile manufacture, plating plants and metallurgical and mechanical processes; and included in the fourth group was waste materials from the mining and metallurgical industries, such as basalt and clay minerals and quartz, feldspar and carbonates from rock and mineral processes.

In recent years, following Dondi et al., many researchers have presented reviews on the reuse of waste in bricks. Raut et al. (3) analysed the attempts to use industrial and agricultural solid waste in the production of bricks; for instance, the use of paper processing residues, cigarette butts, textile effluent treatment plant sludge, polystyrene foam, fly ash, plastic fibre, straw, cotton waste, rice husk ash, granulated blast furnace slag, limestone dust and wood sawdust, processed waste tea, and petroleum effluent treatment plant sludge, among others. In addition to the type of waste and its percentage, the size of brick mould, drying and firing/curing temperatures and the tests performed were shown. In our review, Aeslina et al. (4) introduced the improvement of certain properties in clay bricks using different averages of waste. In this case, a similar classification to Dondi et al. was used: sludge, fly ash and other waste. Zhang's review (5) showed similar data to Raut et al., but using a different classification: production of bricks from waste materials through firing, production of bricks from waste materials through cementing, and production of bricks from waste materials through geo-polymerisation. Muñoz et al. (6) displayed similar data to Raut et al. and Zhang, but included the pre-conditioning of raw materials, percentage of mixing water, number of samples, and tests and standards. In their review, waste was divided into organic matter, sludge, ash and inorganic waste and different graphs were used to establish the effect of the firing temperature on the brick properties according to the type and percentage of waste used. Finally, in their review, Monteiro et al. (7) following Zhang, showed the same data as shown in previous research, but analysed papers written in English and Portuguese.

In our case, the study of sludge generated by aggregate plants was an unusual research topic. Blanco et al. (8) had investigated the use of sludge from washing natural detrital deposits in fired clay bricks. After characterising the use of sludge, dried and crushed by X-ray diffraction (XRD), the mixture was fired at $900,950{ }^{\circ} \mathrm{C}$ and $1000{ }^{\circ} \mathrm{C}$ and lineal contraction, water absorption and colour were studied, concluding that this sludge is applicable in manufactured fired clay ceramics. Some analyses (grain size distribution, textural classification, weight lost at different temperatures, chemical composition) were made in the dissertation by Issaura (9) in order to characterise the residue and to conclude if using it as a ceramic raw material could be profitable. In addition, firing experiments were conducted on some pressed and fired samples made with the residue to know the linear changes on firing samples and water absorption. Issaura concluded that this residue is suitable for manufacturing fired clay bricks and the addition of kaolinite was recommended. Finally, she proposed some changes in the aggregate treatment process to obtain dehydrated clayey cakes with only $20 \%$ humidity.

In Girona province, a large number of aggregate plants can be found, which produce aggregate for the building sector. One of the issues raised in these plants, as in other industries, (1-7) is waste recycling. Basically, this waste is sludge resulting from the aggregate washing process. It cannot be discharged directly into the river with the water because the concentrations of suspended solids it contains exceed $300 \mathrm{mg} / \mathrm{l}$. Consequently, many plants have started to use a decanter and filter press that separate the solid fraction from the liquid, converting the former into sludge. Despite this improvement, this sludge continues to be a disposable waste, since it can only be used as a filler material for cropland (9).

A study was commissioned by the aggregate plant, Arids Guixeras S.A. (Riudarenes - Girona), on the sludge produced at the plant with a view to its commercialisation. The commission budget only permitted analysis of the sludge to define its chemical composition. In spite of this, it was decided to continue with the study of this waste product since, potentially, a wide field of application exists for it in the manufacture and enhancement of commonlyused building materials. At the same time, if a use could be found for this waste, the environmental impact of this particular aggregate plant would be considerably reduced and, more importantly, it would pave the way for other aggregate plants to follow suit.

Different possibilities for the use of this sludge in the manufacture of various types of building materials were considered. It could be used as an 
addition to enhance mortar; it could also be used to make porcelain stoneware floor tiles; it could be incorporated as a material, mixed with earth, to manufacture compressed earth blocks (CEB); and also as an additional material to enhance the properties of porous ceramics used in building.

In this study, the use of sludge in the manufacture of porous fired clay bricks was analysed. This does not mean that its use in the previously mentioned materials has been dismissed. On the contrary, other avenues of research have been left completely open because it is believed that the use of sludge to enhance the properties of porcelain stoneware, CEB, mortar and other construction materials is perfectly viable. If it was opted to study its implementation in porous fired clay bricks, it is due to the similarities in the mineral composition of sludge and clay (10).

In this paper, the first results obtained from using sludge in the manufacture of porous ceramic bricks for building are presented. The preliminary analysis to define these materials includes the chemical characterisation of the raw materials and the study of the physical and mechanical properties of the finished product, using different dosages.

\section{MATERIALS AND METHODS}

\subsection{Materials}

The materials used to manufacture the porous fired clay bricks were clay, supplied by Argiles Colades S.A., a company specialising in clay extraction and handling, sludge, derived from aggregate and sand washing, and sand. Two different kinds of sand were used: commercial sand and standard sand. The latter contains about $94.25 \%$ of $\mathrm{SiO}_{2}$ and only $0.93 \%$ of $\mathrm{CaO}(11)$. The addition of sand Argiles Colades S.A. use sand in their production in the manufacture of the porous fired clay bricks was considered because the use of clay alone does not lead to a good quality product, since the plasticity level is high and the addition of sand reduces shrinkage in the firing process. Nonetheless, in principle, two sands should be compatible with the clay and sludge used.

As neither the proportions of the materials to be used nor information regarding firing times and temperature were available, a theoretical framework was constructed based on the data obtained in preliminary clay and sludge testing. The decision to use dry residue and then incorporate water was taken in order to assure the same quantity of water in all specimens and guarantee their homogeneity. Table 1 shows the definitive proportions of all the materials used in the mix. It was deemed suitable to make a reference specimen in which only clay was used, and another in which only sludge was used, even though it was already suspected that it was impossible to make porous fired clay bricks using these materials
TABLE 1. Dosage of samples

\begin{tabular}{|c|c|}
\hline Code & Compotion \\
\hline $\mathrm{C} 1$ & $\begin{array}{l}90 \% \text { clay }+10 \% \text { sludge }+20 \% \text { standard sand }+ \\
10.7 \% \text { water }\end{array}$ \\
\hline $\mathrm{C} 2$ & $\begin{array}{l}80 \% \text { clay }+20 \% \text { sludge }+20 \% \text { standard sand }+ \\
10.7 \% \text { water }\end{array}$ \\
\hline C 3 & $\begin{array}{l}70 \% \text { clay }+30 \% \text { sludge }+20 \% \text { standard sand }+ \\
10.7 \% \text { water }\end{array}$ \\
\hline $\mathrm{C} 4$ & $\begin{array}{l}60 \% \text { clay }+40 \% \text { sludge }+20 \% \text { standard sand }+ \\
10.7 \% \text { water }\end{array}$ \\
\hline $\mathrm{C} 5$ & $\begin{array}{l}50 \% \text { clay }+50 \% \text { sludge }+20 \% \text { standard sand }+ \\
10.7 \% \text { water }\end{array}$ \\
\hline FC 1 & $\begin{array}{l}100 \% \text { sludge }+20 \% \text { sand from aggregate plant }+ \\
10.7 \% \text { water }\end{array}$ \\
\hline FC 2 & $100 \%$ sludge $+20 \%$ standard sand $+10.7 \%$ water \\
\hline V 1 & $\begin{array}{l}100 \% \text { clay }+20 \% \text { sand from aggregate plant }+ \\
10.7 \% \text { water }\end{array}$ \\
\hline $\mathrm{V} 2$ & $100 \%$ clay $+20 \%$ standard sand $+10.7 \%$ water \\
\hline
\end{tabular}

in isolation. Despite the fact that some authors limit the proportion of waste to be added to a maximum of $30 \%(6)$, we chose to increase this percentage in two of the selected dosages.

\subsection{Experimental techniques}

Different tests to characterise the sludge were implemented: X-ray diffraction (XRD), X-ray fluorescence XRF, elemental analysis (CNHS), carbonate content and TGA-DTA. For the characterisation of clay and commercial sand, two tests only were carried out - XRD and carbonate content in order to compare these results to the chemical composition of the sludge provided by the manufacturer.

The chemical composition of the mud, clay and sand were determined by XRD with a Bruker D8 Advance powder diffractometer, with BraggBrentano Theta-2Theta geometry with copper $\mathrm{K}_{\text {alfa }}$ radiation $(\lambda=\AA)$ and $40 \mathrm{kV}$ and $40 \mathrm{~mA}$. A secondary graphite monochromator was used and the angle range scanned was 4 to $50^{\circ} 2$ Theta with a step size of $0.05^{\circ}$ and a scan step of $13,15,10$ and 6 seconds. The samples were previously dried in an electric kiln for 96 hours at $100^{\circ} \mathrm{C}$ and ground in a planetary ball mill before being positioned in the sample holder.

The quantitative chemical composition of the sludge was determined by energy dissipation X-ray efflorescence spectrometer (EDXRF) S2 RANGER (Bruker AXS, GmbH, Germany) of multi-elemental simultaneous analysis with $\mathrm{X}$-ray tube with anode de Pd (Pmax: $50 \mathrm{~W}$, Vmax: $50 \mathrm{kV}$, Imax: $2 \mathrm{~mA}$ ) fitted out with 9 primary filters, signal detector XFlash TM with technology SDD (Silicon Drift Detector), refrigerated by Peltier. Rank of detection: of Sodium $(\mathrm{Na})$ and Uranium $(\mathrm{U})$, resolution $100000 \mathrm{cps}$ is $<129 \mathrm{eV}$ for $\mathrm{Mn} \mathrm{K \alpha}$. 
Other tests were done with the purpose of characterising the sludge accurately. Firstly, a CNHS was conducted to determine the amount of $\mathrm{C}, \mathrm{H}$ and N with Perkin Elmer EA2400 series II and microbalance Sartorius 2MP and then a carbonate content test was carried out - clay and sand too using a Bernard calcimeter obtaining $\mathrm{CO}_{2}$ volume and $\mathrm{CaCO}_{3}$ percentage using a $6 \mathrm{ml}$ dissolution of $\mathrm{HCl} 6 \mathrm{~N}$ and 0.2 gr of pure $\mathrm{CaCO}_{3}$.

In order to complete the sludge characterisation, a thermogravimetric (TGA) and a thermodifferential (DTA) analysis were carried out with METTLER TOLEDO, model TGA/DSC 1 with resolution balance $1 \mu \mathrm{g}$ and $\pm 0.5^{\circ} \mathrm{C}$, heating of $30{ }^{\circ} \mathrm{C}$ to $800^{\circ} \mathrm{C}$ with $20^{\circ} \mathrm{C} / \mathrm{min}$ speed, atmosphere of synthetic air with a wealth of purge $40 \mathrm{ml} / \mathrm{mm}$ and melting-pot of alumina with $150 \mu \mathrm{l}$ of capacity.

To make the mix; first, the sludge, which contained an excess of water, was dried in a drying oven at $60^{\circ}$ for 56 hours (in order not to alter the properties of the raw material), to completely remove all the water it contained. It was then ground in a mill.

Before making the test specimens, sediment testing was carried out on both the sludge and the clay, according to the Spanish UNE 103102:95 standards (12) to determine particle size, and the Atterberg Limits test, according to UNE standards 103103:94 (13) and 103104:93 (14) to determine the liquid and plastic limits, respectively. These tests enabled us to determine, with a reliable degree of accuracy, the amount of water to be added to the mixture used to make the specimens.

Before firing the different mixes used to make the fired clay bricks, shrinkage testing (to determine dry shrinkage and shrinkage-induced cracking) was performed on the specimens. An alternative system to the UNE and ASTM standards $(15,16)$ was used to prevent handling the highly-toxic mercury. This system was devised by Dr. Gabriel Barbeta and carried out on $60 \times 6 \times 4 \mathrm{~cm}$ specimens (17).

After mixing the different combinations with $10.7 \%$ water, the fired clay specimens were pressed into $14.4 \times 7 \times 7 \mathrm{~cm}$ metal moulds. Apart from the manual pressure applied during the mould-filling process, a brick press, applying a pressure of $20 \mathrm{~kg} / \mathrm{cm}^{2}$, was used to simulate large-scale manufacture with an extrusion machine or extrusion press. Before being put in the kiln, the specimens were left for 2 to 3 days in the humidity chamber to lose between $3 \%$ and $5 \%$ of their weight, thereby preventing shrinkage-induced cracks.

Brick firing was carried out in an electric fixedbase Mannetti K150/12 kiln with Aero electronic MPS programmer with memory for 4 firing cycles of 8 segments each, power: $9 \mathrm{Kw}$, supply voltage $400 \mathrm{~V} 50 \mathrm{~Hz}$, and maximum temperature, $1280^{\circ} \mathrm{C}$. The temperature was gradually increased and left to decrease, also gradually, once the maximum temperature had been reached. The chosen firing cycles are shown in Figure 1. Before choosing the maximum firing temperatures, it was carried out on specimens at 900 and $950{ }^{\circ} \mathrm{C}$, but the consistency of the specimens was bad, due most probably to low manufacture pressure. Finally, it was decided to use the maximum firing temperatures 1000 and $1050{ }^{\circ} \mathrm{C}$. Issaura (9) underlines that the optimum firing temperature to ensure the mechanical resistance of the specimen is between 1000 and $1050{ }^{\circ} \mathrm{C}$ as the resulting $\mathrm{CaO}$ reacts with clay materials and free silica to form calcium silicates. Another reason for choosing these temperature ranges, as mentioned in section 2.1, was a theoretical choice as the manufacturers were reluctant to provide exact details of the manufacturing process. On the other hand, in the literature regarding the use of recycled products to make ceramics, researchers used a wide range of firing temperatures, from 700 to $1100{ }^{\circ} \mathrm{C}(1-7)$.
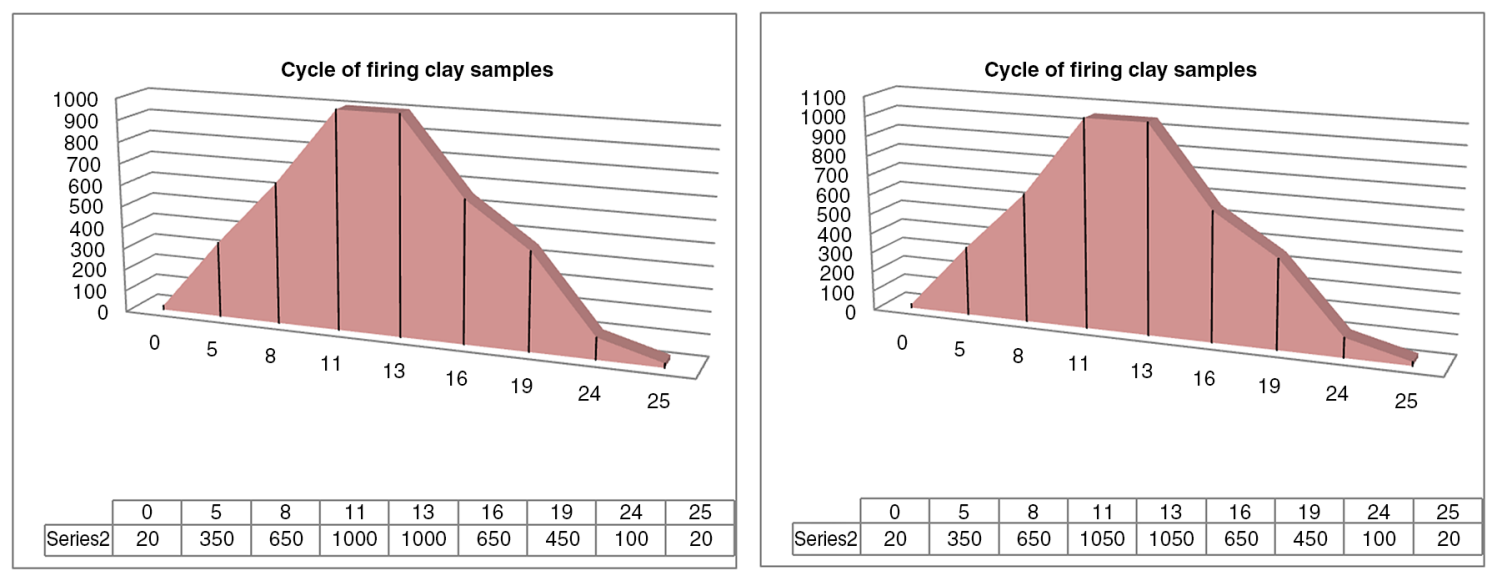

Figure 1. Cycle of firing clay to $1000^{\circ} \mathrm{C}$ and $1050^{\circ} \mathrm{C}$ 
The following tests were carried out on the fired specimens: true density (this did not include pore volume), and apparent density testing (including pore volume), according to the Spanish UNE 103301:1994 and UNE 103105:1993 standards $(18,19)$; absorption test, according to UNE-EN 77221:2011 (20); a capillary absorption test, according to UNE-EN 72211:2011 (21); a compressive strength test, according to UNE-EN 7721:2011 (22); a wet-frost-dry test, devised by Dr. Gabriel Barbeta (17), based on standards $\operatorname{ASTM}(23,24), \operatorname{NLT}(25)$ and UNE (26); thermal conductivity measurement (a test at the experimental stage, very similar to the one used by other researchers), and the calibrated hot box test $(27,28)$. Finally, to characterise the fired specimen in order to relate microstructure with properties, a scanning electronic microscopy analysis (SEM) was used, composed of Zeiss DSM 960A (20x to 2000000x) fitted out with signal detectors SE, BSE, CL; X-Ray by dissipation energies and microanalysis of X-ray Bruker Quantas 200 (resol.125 eV) associated to MER.

To determine the thermal conductivity of the fired clay bricks, test equipment developed by the Physics Department of the University of Girona was used. This equipment had been used successfully in thermal insulation, but it was the first time it had been used with a material such as fired clay. Consequently, a solid brick, whose thermal conductivity was known, was used as a reference. The first step was to prepare the cube-shaped specimens, which were covered with polystyrene. To seal the joints, tightly-pressed adhesive tape was used to avoid air-filled gaps. At the same time, the electric hot plate was turned on until a constant temperature of $60{ }^{\circ} \mathrm{C}$ was reached. Then, the samples to be analysed were positioned between the thermal appliances, ensuring that they were perfectly centred and aligned; two above and two below. The movable platform was then lowered and the screws tightened to ensure everything was securely anchored. The fan was turned on and the specimens were left to reach a steady state. The test could be considered over when no notable change in temperature had been registered in consecutive readings. In this case, readings were carried out every half hour and ten minutes later to check thermal variations. In our study, the test lasted one and a half hours. Thermal conductivity was determined by applying formulas [1] and [2]:

$$
\lambda=\left[F \times \frac{\text { Eapecimen }}{T_{2}-T_{3}}\right]
$$

Where $F$ is heat flow in $\mathrm{W} / \mathrm{m}^{2}, \lambda$ is thermal conductivity in $\mathrm{W} / \mathrm{m} . \mathrm{K}, T$ is temperature of thermal appliance in ${ }^{\circ} \mathrm{C}$ and $\mathrm{E}$ is thickness reference specimens in $\mathrm{m}$.

As a satisfactory result was not obtained with the previously mentioned equipment, we decided to repeat the test in a custom-made calibrated thermal box, following the Spanish UNE-EN ISO 8990:1997 standard (29). The equipment was made up of 4 type $K$ thermocouples and readout of the same characteristics. The thermostat temperature of the thermal box was regulated at $40{ }^{\circ} \mathrm{C}$ and the resistor was automatically deactivated when the temperature reached a maximum of between 70 and $80{ }^{\circ} \mathrm{C}$, falling sharply to $50{ }^{\circ} \mathrm{C}$. When the temperature reached 36 or $37^{\circ} \mathrm{C}$, the resistor was triggered by the thermostat, starting a new cycle. To perform this test, the simple specimens had to be cut to adapt their dimensions to the box (Figure 2). The thermocouples were attached with aluminium adhesive tape; natural stone wool was placed between them and the filament to prevent the thermocouples reading the temperature of the tape or the temperature due to radiation. Readings began when the calibrated box reached a steady state, the estimated time of which was about 10 hours.

To validate the results obtained in this test, the box was calibrated using a manufactured porous fired clay brick of a similar size to our specimens. The values obtained were related to the standard values in Table 2 (30). In this table, thermal conductivity is related to the range of density of artificial materials, among which is fired clay of treated soils.

In the thermal conductivity test, the temperature in the hot chamber $\left(T_{\mathrm{c}}\right)$, the temperature in the cold chamber $\left(T_{\mathrm{f}}\right)$, the temperature on the hot face $\left(T_{1}\right)$ and the temperature on the cold face $\left(T_{2}\right)$ were obtained. These temperatures were the mean of the temperature readings carried out every 5 minutes from the moment the resistor was activated, and until it was activated again. Once the surface and the thickness of the sample had been measured, the surface resistance of the specimen faces $\left(R_{\mathrm{si}}\right)$ was obtained based on the Support Document of the Basic Document, Savings Power/1 section 2: Calculation of characteristics parameters of surrounding (DA DB-HE/1) (31). In our study, the $R_{\mathrm{si}}$ value equalled $0.13 \mathrm{~m}^{2} . \mathrm{K} / \mathrm{W}$, taking into account that the conditions in the interior of

$$
F=\left[\frac{\lambda \text { lower pattern } \times \frac{\left(T_{1}-T_{2}\right)}{E \text { lower pattern }}+\lambda \text { upper pattern } \times \frac{\left(T_{3}-T_{4}\right)}{E \text { upper pattern }}}{2}\right]
$$



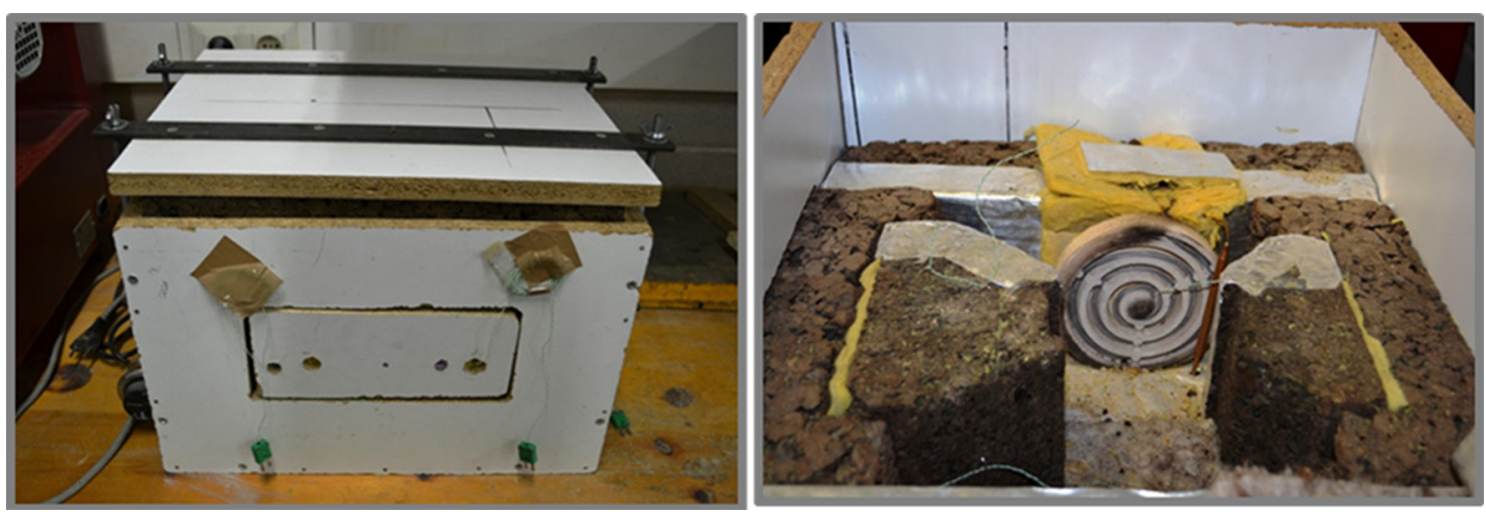

FIGURE 2. Thermal box

TABLE 2. Table of thermal conductivity. Source: CTE. Catalogue of Building elements, Instituto Eduardo Torroja de la Construcción, Spain

\begin{tabular}{|c|c|c|c|c|}
\hline \multicolumn{5}{|c|}{ Artificial materials or soils treated } \\
\hline \multirow[b]{2}{*}{ Material } & \multicolumn{4}{|c|}{ HE } \\
\hline & $\rho \mathrm{kg} / \mathrm{m}^{3}$ & $\lambda \mathrm{W} / \mathrm{m} . \mathrm{K}$ & Cp J/ kg.K & $\mu$ \\
\hline \multirow[t]{15}{*}{ Ceramic brick for building work (1) } & $2300<\rho \leq 2400$ & 0.90 & 1000 & 10 \\
\hline & $2200<\rho \leq 2300$ & 0.85 & 1000 & 10 \\
\hline & $2100<\rho \leq 2200$ & 0.79 & 1000 & 10 \\
\hline & $2000<\rho \leq 2100$ & 0.74 & 1000 & 10 \\
\hline & $1900<\rho \leq 2000$ & 0.69 & 1000 & 10 \\
\hline & $1800<\rho \leq 1900$ & 0.64 & 1000 & 10 \\
\hline & $1700<\rho \leq 1800$ & 0.59 & 1000 & 10 \\
\hline & $1600<\rho \leq 1700$ & 0.55 & 1000 & 10 \\
\hline & $1500<\rho \leq 1600$ & 0.50 & 1000 & 10 \\
\hline & $1400<\rho \leq 1500$ & 0.46 & 1000 & 10 \\
\hline & $1300<\rho \leq 1400$ & 0.43 & 1000 & 10 \\
\hline & $1200<\rho \leq 1300$ & 0.39 & 1000 & 10 \\
\hline & $1100<\rho \leq 1200$ & 0.35 & 1000 & 10 \\
\hline & $1000<\rho \leq 1100$ & 0.32 & 1000 & 10 \\
\hline & $\rho \leq 1000$ & 0.29 & 1000 & 10 \\
\hline Artificial stone & $\rho \leq 1750$ & 1.30 & 1000 & 40 \\
\hline $\begin{array}{l}\text { Rammed earth, Sun-dried brick, } \\
\text { Compressed earth blocks }\end{array}$ & $1770 \leq \rho \leq 2000$ & 1.10 & - & - \\
\hline
\end{tabular}

(1) The design values correspond to a percentile of $90 \%$ and come from the declared values obtained under the UNE EN 1745:2002 and corrected according to the criteria of the UNE EN 12524:2000, with a correction factor for humidity, $F_{\mathrm{m}}$, equal to 1.07 .

the box were for horizontal heat flow and the closure was vertical, or with a slope greater than $60^{\circ}$ on the horizontal plane.

To calculate thermal conductivity, we followed the following steps. Firstly, heat flow was calculated based on the formula [3]:

$$
Q=\frac{S \cdot \lambda \cdot\left(T_{1}-T_{2}\right)}{e}
$$

Where $Q$ is heat flow in $W, S$ is surface in $\mathrm{m}^{2}, \lambda$ is thermal conductivity coefficient in $\mathrm{W} / \mathrm{m} .{ }^{\circ} \mathrm{C}$,

$T_{1}-T_{2}$ is increase in temperature between the specimen faces in ${ }^{\circ} \mathrm{C}$ and $e$ thickness in $\mathrm{m}$.

We then calculated the amount of heat passing through the specimen per unit of time using the formula [4]:

$$
Q=S \cdot U \cdot\left(T_{c}-T_{f}\right)
$$


Where $Q$ is heat flow expressed in $W, S$ is surface in $\mathrm{m}^{2}, U$ is transmittance expressed in $\mathrm{W} / \mathrm{m}^{2} .{ }^{\circ} \mathrm{C}$ and $\left(T_{\mathrm{c}}-T_{\mathrm{f}}\right)$ is increase in air temperature between hot and cold chamber in ${ }^{\circ} \mathrm{C}$

The next step was to calculate the inside surface of the specimen based on the formula [5]:

$$
T_{1}=T_{c} \cdot \frac{\left(T_{c}-T_{f}\right) \cdot U}{h i}
$$

Where $T_{1}$ is temperature hot face of the specimen in ${ }^{\circ} \mathrm{C}, T_{\mathrm{c}}$ is temperature hot chamber in ${ }^{\circ} \mathrm{C}$, $\left(T_{\mathrm{c}}-T_{\mathrm{f}}\right)$ is increase in air temperature of the hot and cold chamber in ${ }^{\circ} \mathrm{C}, U$ is transmittance expressed in $\mathrm{W} / \mathrm{m}^{2}{ }^{\circ} \mathrm{C}$ and hi is internal heat transfer coefficient $\left(1 / \mathrm{hi}=R_{\mathrm{si}}\right)$

Based on these previous formulas, we obtained the transmittance formula [6] and the thermal conductivity formula [7]:

$$
\begin{aligned}
& U=\frac{\left(T_{c}-T_{1}\right)}{\left(T_{c}-T_{f}\right) \cdot R_{\mathrm{si}}} \\
& \lambda=\frac{e \cdot U \cdot\left(T_{c}-T_{f}\right)}{\left(T_{1}-T_{2}\right)}
\end{aligned}
$$

Where $U$ is the transmittance in $\mathrm{W} / \mathrm{m}^{2} .{ }^{\circ} \mathrm{C}, T_{\mathrm{c}}$ is temperature of hot chamber in ${ }^{\circ} \mathrm{C}, T_{1}$ is temperature hot face of specimen in ${ }^{\circ} \mathrm{C},\left(T_{\mathrm{c}}-T_{\mathrm{f}}\right)$ is increase in air temperature between hot and cold chambers in ${ }^{\circ} \mathrm{C}, R_{\mathrm{si}}$ is internal surface thermal resistance $\left(0.13 \mathrm{~m}^{2} .{ }^{\circ} \mathrm{C} / \mathrm{W}\right), \lambda$ is thermal conductivity coefficient in $\mathrm{W} / \mathrm{m} .{ }^{\circ} \mathrm{C}, e$ is thickness in $\mathrm{m}$ and $\left(T_{1}-T_{2}\right)$ is increase in temperature between specimen faces in ${ }^{\circ} \mathrm{C}$.

\section{RESULTS AND DISCUSSION}

\subsection{Characterisation of raw materials}

Three sludge samples were collected in situ at the aggregate plant and taken to the Technical Research Services of the University of Girona to be analysed; X-ray diffraction was performed (Figure 3). Basically, all the samples contained the same minerals, with a few variations. The main component of the sludge was quartz and mica biotite. In all the samples, Feldspars (anortite and albite), potassium feldspar (sanidine), calcite and clays (montmorillonite and kaolinite) appear as minor components. The EDXRF shows the oxides that form part of the minerals quoted previously. The most important amount corresponds to $\mathrm{SiO}_{2}$ and $\mathrm{Al}_{2} \mathrm{O}_{3}$ that quartz mineral is made up of. The important amount of $\mathrm{Fe}_{2} \mathrm{O}_{3}$ should also be mentioned. Regarding the minor elements, only the amount of Ti (Table 3) should be underlined. Thus, this sludge proved to be suitable for mixing with clay as their components were compatible. Although montmorillonite is a mineral with considerable expansion properties, this did not pose a problem during the specimen manufacturing process. Conversely, kaolinite confers a low plasticity to sludge and has excellent drying properties.

With TGA-DTA analysis the effect of temperature on this sludge can be underlined. Three samples of sludge were analysed with similar results. In the signal TGA (loss of mass), four steps can be observed. In the first, between 100 and $180{ }^{\circ} \mathrm{C}$, the sample loss of its superficial water absorbed and water from the mineral structure. In the ranking order of decomposition of organic materials, between 230 and $370^{\circ} \mathrm{C}$, the loss of mass is marginal indicating a low amount of these. Dehydroxylations of compound minerals appear between 370 and $620{ }^{\circ} \mathrm{C}(32-34)$. Finally, between 620 and $720{ }^{\circ} \mathrm{C}$, decomposition of carbonates takes place to form the respective oxides (35). In the DTA signal the same peaks can be shown in concordance with the TGA signal. The first two endothermic peaks at 110 and $180^{\circ} \mathrm{C}$ in relation to loss of water absorbed and crystallisation. The next peak, now exothermic, at around $330{ }^{\circ} \mathrm{C}$, is related to iron oxidation (32). Finally, the dihydroxylation peak (around $535^{\circ} \mathrm{C}$ ) and decomposition of carbonates (around $700{ }^{\circ} \mathrm{C}$ ) were observed (Figure 4).

Regarding the clay used, the company Argiles Coladas S.A. provided information on its mineral and chemical composition and grain size (Table 4). In order to check qualitatively the chemical composition provided by the company, two samples were tested with a XRD. The results coincide and this clay was formed by quartz, calcite, plagioclase feldspar, potassium feldspar and clays (chloriteserpentine, montmorillonite, illite and kaolinite) (Figure 5). To complete this analysis we carried out a carbonate content test (Table 5). The amount of $\mathrm{CaCO}_{3}(6.75 \%)$ was in concordance with the content of $\mathrm{CaO}(4.62 \%)$ provided by the manufacturer.

Grain size distribution analysis on the sludge revealed that $20 \%$ was fine sand and the rest, silt. $44 \%$ of the total sample weight corresponded to particles with a diameter the same or greater than $0.0325 \mathrm{~mm}$. On the other hand, the clay did not contain fine sand and $42 \%$ of its total weight corresponded to particles whose diameter was greater than $0.013 \mathrm{~mm}$ (Figure 6). Hence, the sludge provided particles with a larger diameter so the amount of sand added to the fired clay brick mixture could be reduced.

In the Atterberg Limits test on the sludge, performed on three samples, we obtained a liquid limit of $39 \%$ and a plastic limit of $28.27 \%$, giving a plasticity index of $10.73 \%$. In the case of the clay, also performed on three samples, we obtained a liquid limit of $30 \%$ and a plastic limit of $21.40 \%$, giving 

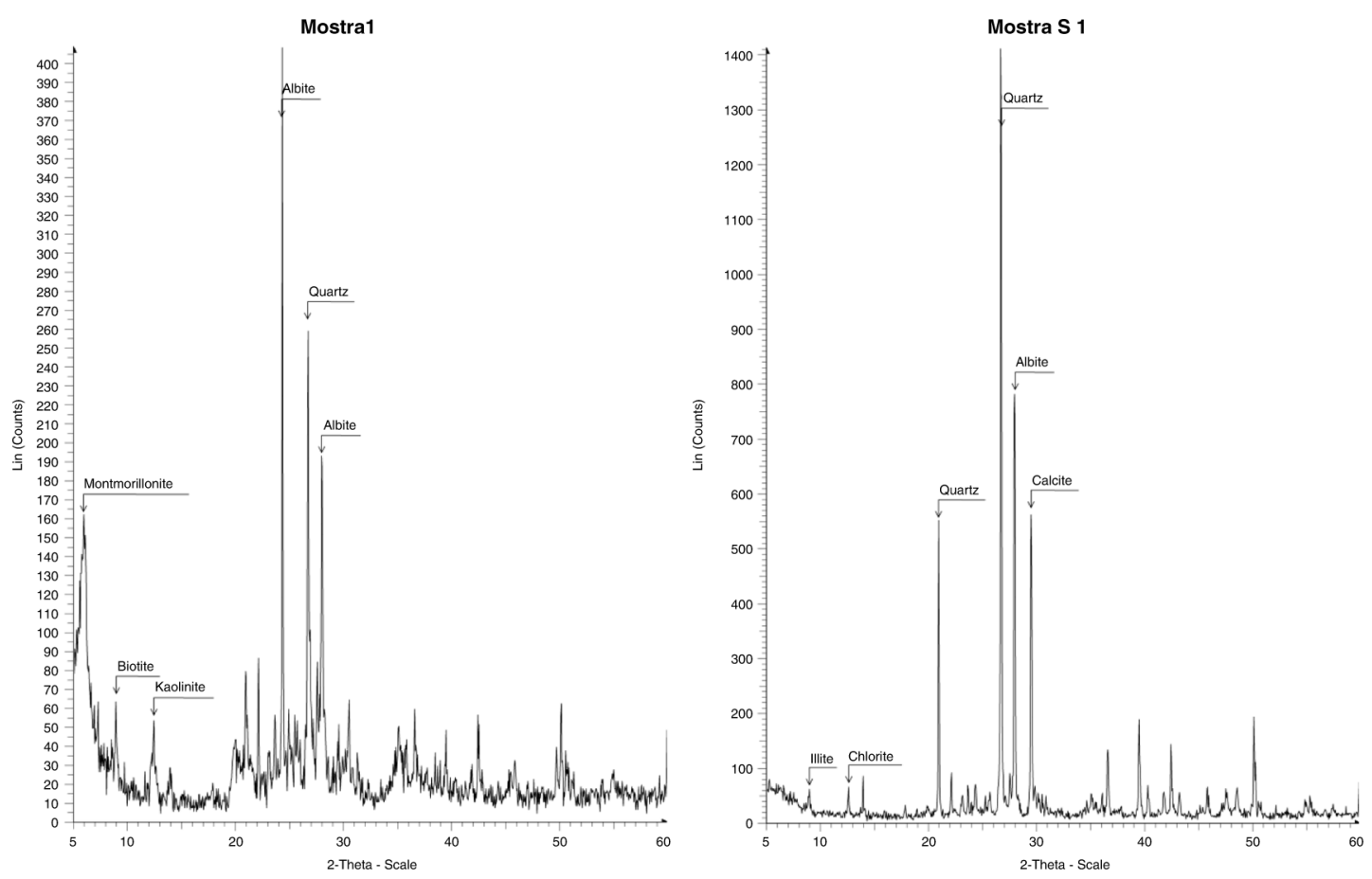

Figure 3. X-ray diffraction. Mostra 1 (sludge) and, S1 (sand)

TABle 3. Energy dissipation X-ray efflorescence of sludge

\begin{tabular}{lccc}
\hline & $\begin{array}{c}\text { Sample-1 } \\
\text { \% }\end{array}$ & $\begin{array}{c}\text { Sample-2 } \\
\%\end{array}$ & $\begin{array}{c}\text { Sample-3 } \\
\%\end{array}$ \\
\hline Main elements & & & \\
$\mathrm{Na}_{2} \mathrm{O}$ & 1.34 & 1.21 & 1.48 \\
$\mathrm{MgO}$ & 2.33 & 2.44 & 2.52 \\
$\mathrm{Al}_{2} \mathrm{O}_{3}$ & 13.90 & 13.80 & 13.70 \\
$\mathrm{SiO}_{2}$ & 62.10 & 62.60 & 61.80 \\
$\mathrm{~K}_{2} \mathrm{O}$ & 3.91 & 3.92 & 3.98 \\
$\mathrm{CaO}$ & 3.67 & 3.82 & 3.66 \\
$\mathrm{TiO}_{2}$ & 1.32 & 3.82 & 1.29 \\
$\mathrm{Fe} \mathrm{O}_{3}$ & 8.89 & 9.02 & 8.95 \\
$\mathrm{Minor}$ elements & & & \\
$\mathrm{S}$ & 0.040 & 0.020 & 0.040 \\
$\mathrm{Ti}$ & 0.790 & 0.800 & 0.820 \\
$\mathrm{Mn}$ & 0.039 & 0.037 & 0.044 \\
$\mathrm{Cu}$ & 0.010 & 0.008 & 0.011 \\
$\mathrm{Zn}$ & 0.019 & 0.018 & 0.021 \\
$\mathrm{Rb}$ & 0.035 & 0.035 & 0.038 \\
$\mathrm{Sr}$ & 0.018 & 0.017 & 0.019 \\
$\mathrm{Y}$ & 0.015 & 0.013 & 0.016 \\
$\mathrm{Zr}$ & 0.048 & 0.044 & 0.049 \\
$\mathrm{Nb}$ & 0.009 & 0.007 & 0.009 \\
$\mathrm{~Pb}$ & 0.007 & 0.008 & 0.009 \\
\hline
\end{tabular}

a plasticity index of $8.60 \%$ (Table 6). Therefore, as these indexes are below those recommended for manufacturing fired clay bricks $(15 \%-25 \%)$, we can assert that these two materials cannot be used in isolation (10). Based on these results, we decided to use $10.7 \%$ of water in the mixing process of the new mixtures, since both materials are present.

In the dry retraction test, the behaviour of the sludge and clay were analysed individually and then the mixtures were tested. Neither the sludge nor the clay stood the test as their retraction rates were 5.5\% and $6.05 \%$, respectively, and cracks appeared in the specimen. This same test was carried out on clay specimens mixed with $5-10-15-20 \%$ of fine sand, and on a test specimen with $20 \%$ of standard sand in order to determine the right amount of sand needed by the sample. In the four first samples, the dry retraction value exceeded $3 \%$ but did not exceed the $5 \%$ recommended before firing and cracks appeared only in the sample with $10 \%$ sand. When the specimen with standard sand was tested, the result was below $3 \%$, specifically $2.73 \%$, which meant that this mixture was suitable for manufacturing porous fired clay bricks (Figure 7). Thus, what sand does is reduce the dry retraction rate. With $15 \%$ more sand, retraction was reduced by $16.26 \%$.

As a result of these tests, the percentages used in each mixture were determined; the proportion of clay being greater than the other materials. The five specimens for each of the initial mixtures containing clay/sludge ratios of $90 / 10,80 / 20,70 / 30$, 


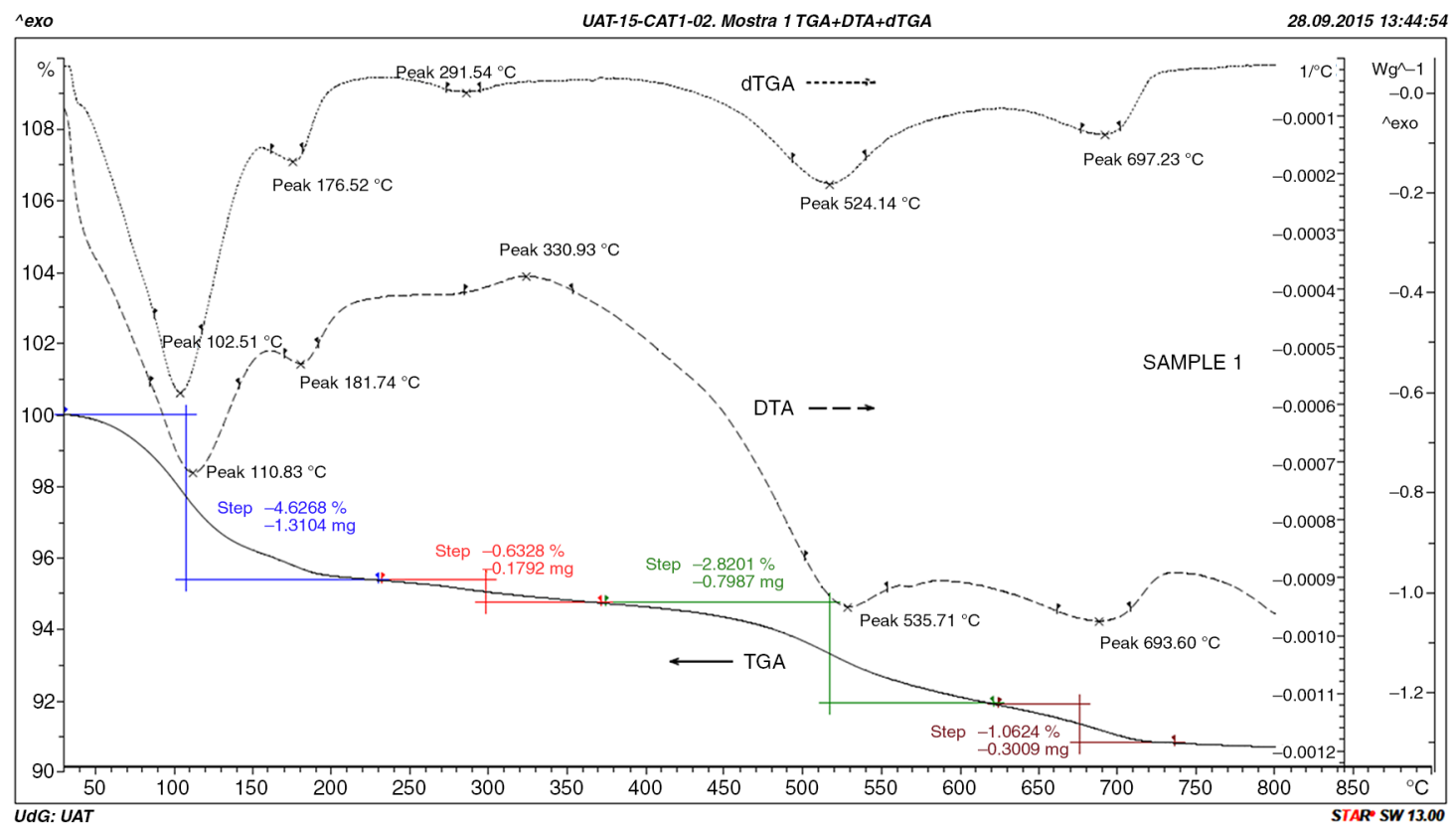

FIgURE 4. DTA-TGA analysis of sludge (sample 1)

TABle 4. Composition of clay. Source: Argiles Colades, S.A.

\begin{tabular}{|c|c|c|c|c|c|c|c|c|c|c|c|c|c|}
\hline \multicolumn{14}{|c|}{ Mineralogical composition } \\
\hline & & \multirow{2}{*}{\multicolumn{12}{|c|}{ Chemical composition }} \\
\hline Montmorillonite & 3.0 & & & & & & & & & & & & \\
\hline Chlorite & 2.0 & & & & & & & & & & & & \\
\hline Illite & 2.4 & Oxide & $\mathrm{Na}_{2} \mathrm{O}$ & $\mathrm{MgO}$ & $\mathrm{Al}_{2} \mathrm{O}_{3}$ & $\mathrm{SiO}_{2}$ & $\mathrm{P}_{2} \mathrm{O}_{3}$ & $\mathrm{~K}_{2} \mathrm{O}$ & $\mathrm{CaO}$ & $\mathrm{TiO}_{2}$ & $\mathrm{MnO}$ & $\mathrm{Fe}_{2} \mathrm{O}_{3}$ & L.o.I. \\
\hline Kaolinite & 9.0 & $\%$ & 0.34 & 2.52 & 18.13 & 55.22 & 0.14 & 3.59 & 4.62 & 0.75 & 0.00 & 6.20 & 8.50 \\
\hline Quartz & 43.0 & & & & & & & & & & & & \\
\hline Feldspar K & 4.0 & & & & & & & & & & & & \\
\hline Plagioclase & 5.0 & \multicolumn{12}{|c|}{ Grain size of the sample } \\
\hline Goethite & 0.0 & & & & & & & & & & & & \\
\hline Hematite & 3.0 & Sieve si & (mm) & & & 0.500 & 0.300 & 0.125 & 0.090 & 0.063 & 0.045 & 0.036 & Other \\
\hline Calcite & 7.0 & & & & & 0.00 & 0.00 & 6.13 & 6.81 & 9.71 & 13.53 & 36.02 & 27.01 \\
\hline Dolomite & 1.0 & & & & & & & & & & & & \\
\hline
\end{tabular}

$60 / 40$ and 50/50, 100/0, 0/100 with 20\% sand and $10.7 \%$ water could not be used. This was because, after having been fired and removed from the kiln, they exploded. Lime nodules appeared after about 12 hours, on contact with $\mathrm{CO}_{2}$ in the atmosphere, increasing the volume of the specimens and causing almost all of them to fracture $(3,36)$. In contrast, the five specimens made with $100 \%$ clay and with $100 \%$ sludge with the addition of $20 \%$ standard sand and the same quantity of water, did not have any problems (Figure 8). In order to determine the apparition of nodules we tested two samples of sand with a XRD and carbonate content test. The XRD test revealed that the main component of the sand was quartz, but it also contained calcite, and the secondary elements that appeared were plagioclase feldspar (albite), potassium feldspar (sanidine) and clays (chlorite-serpentine, montmorillonite, illite and kaolinite). Carbonate content analysis confirmed the XRD results as the amount of $\mathrm{CaCO}_{3}$ was $11.95 \%$ and $12.64 \%$ in crushed sand. The test specimens had to be made again following the same dosages, but using standard sand (Table 1).

Regarding the density of the specimens and, therefore, of the finished product, it was between 1.55 and $1.69 \mathrm{~g} / \mathrm{cm}^{3}$ (Table 7). The dosage in this case did not play a decisive role in varying product density. However, what was observed was that the greater the density, the less porous the specimen was and, in this case, the specimen with the greatest 

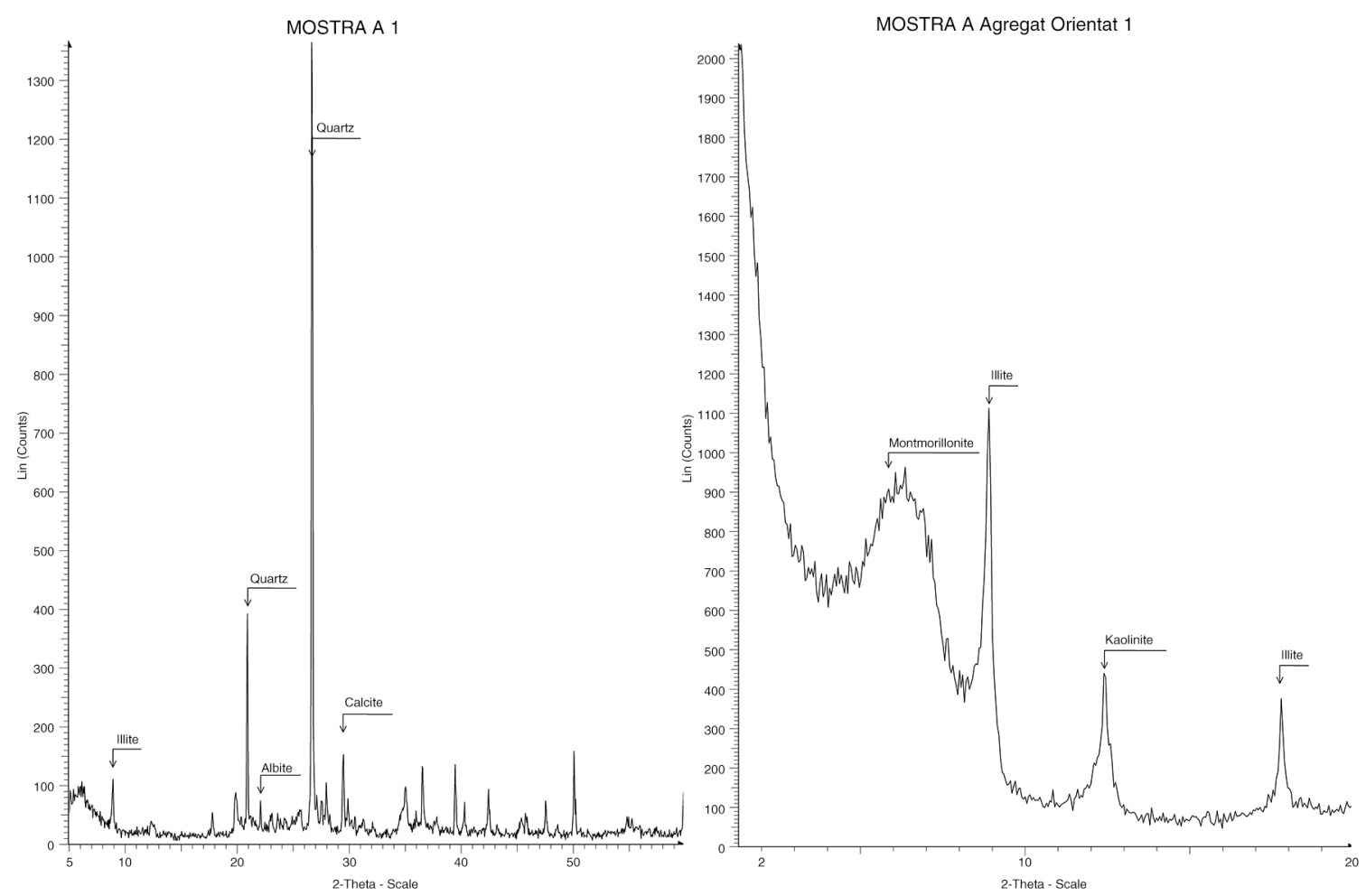

Figure 5. X-ray diffraction. Mostra A1 (clay) and mostra A Agregat orientat (clay trimmed aggregate)

TABLE 5. Carbonates content

\begin{tabular}{lcccc}
\hline Carbonates & Media data $\mathbf{~ m l ~} \mathbf{C O}_{2}$ & Media data $\% \mathbf{C O}_{\mathbf{3}} \mathbf{C a}$ & Standard deviation $\mathbf{C O}_{\mathbf{3}} \mathbf{C a}$ & $\begin{array}{c}\text { Standard relative deviation or coefficient } \\
\text { of variation } \mathbf{C O}_{3} \mathbf{C a}\end{array}$ \\
\hline Mud & 5.24 & 1.97 & 0.65 & 32.99 \\
Sand & 15.60 & 11.64 & 0.99 & 8.51 \\
Clay & 8.35 & 6.75 & 0.42 & 6.22 \\
\hline
\end{tabular}

GRAIN SIZE DISTRIBUTION (MUD)

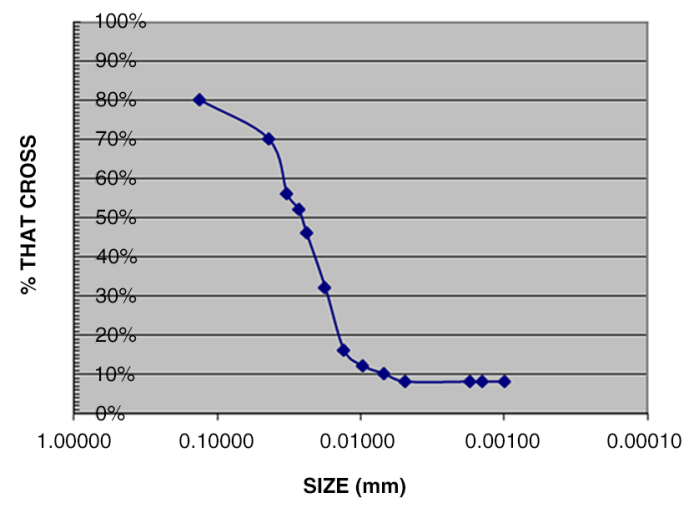

GRAIN SIZE DISTRIBUTION (MUD)

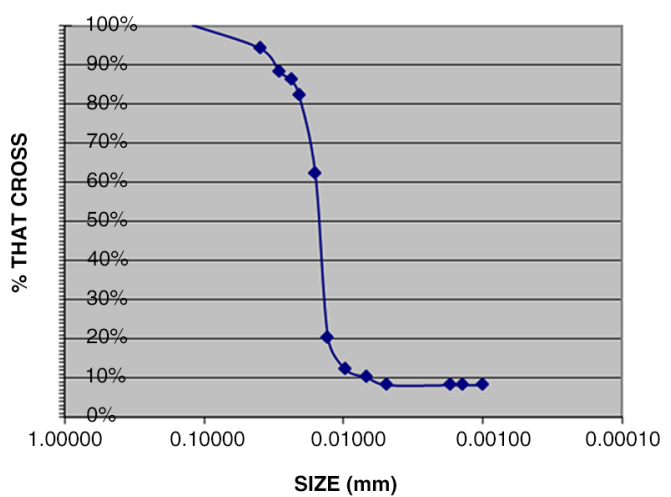

FIGURE 6. Grain size distribution analysis

density was the one in which sludge had not been used in the mixture. The one with the least density was the one in which clay had not been used. Therefore, the porosity of the specimens increased with the addition of sludge.
With regard to water absorption, what the density tests had already manifested was proven. The specimens that absorbed most water were those that only had sludge in the mixture, and those that absorbed the least water were those 
TABLE 6. Atterberg límits

\begin{tabular}{lccclccc}
\hline \multicolumn{1}{c}{ SLUDGE } & Sample 1.4 & Sample 1.5 & Sample 1.6 & \multicolumn{1}{c}{ SLUDGE } & Sample 1.4 & Sample 1.5 & Sample 1.6 \\
\hline $\mathrm{N}^{\text {o } \text { of hits }}$ & 32 & 24 & 35 & Tare + Earth + Water & 17.4 & 16.8 & 15.8 \\
Tare + Earth + Water & 17.4 & 16.8 & 15.8 & Tare + Earth & 16.5 & 16 & 15.3 \\
Tare + Earth & 16.5 & 16 & 15.3 & Tare & 13.4 & 13.4 & 13.3 \\
Tare & 13.4 & 13.4 & 13.3 & Earth & 3.1 & 2.6 & 2 \\
Earth & 3.1 & 2.6 & 2 & Water & $\mathbf{2 9 . 0 3}$ & $\mathbf{3 0 . 7 7}$ & $\mathbf{2 5}$ \\
Water & 0.9 & 0.8 & 0.5 & \% Moisture & & & \\
\% Moisture & $\mathbf{2 9 . 0 3}$ & $\mathbf{3 0 . 7 7}$ & $\mathbf{2 5}$ & & & \\
\hline
\end{tabular}

Liquid limit $=39 \%$

Plastic limit $=28.27 \%$

\begin{tabular}{lccclccc} 
CLAY & Sample 2.4 & Sample 2.5 & Sample 2.6 & CLAY & Sample 2.4 & Sample 2.5 & Sample 2.6 \\
\hline $\mathrm{N}^{\text {o }}$ of hits & 33 & 20 & 11 & Tare + Earth + Water & 26.6 & 26.1 & 25.3 \\
Tare + Earth + Water & 26.6 & 26.1 & 25.3 & Tare + Earth & 26 & 25.6 & 25.1 \\
Tare + Earth & 26 & 25.6 & 25.1 & Tare & 23.6 & 23.5 & 23.8 \\
Tare & 23.6 & 23.5 & 23.8 & Earth & 0.6 & 2.1 & 1.3 \\
Earth & 2.4 & 2.1 & 1.3 & Water & $\mathbf{2 5}$ & $\mathbf{2 3 . 8 1}$ & $\mathbf{1 5 . 3 8}$ \\
Water & 0.6 & 0.5 & 0.2 & $\%$ Moisture & & & \\
\% Moisture & $\mathbf{2 5}$ & $\mathbf{2 3 . 8 1}$ & $\mathbf{1 5 . 3 8}$ & & & \\
\hline
\end{tabular}

Liquid limit $=30 \%$

Plàstic limit $=21.40 \%$
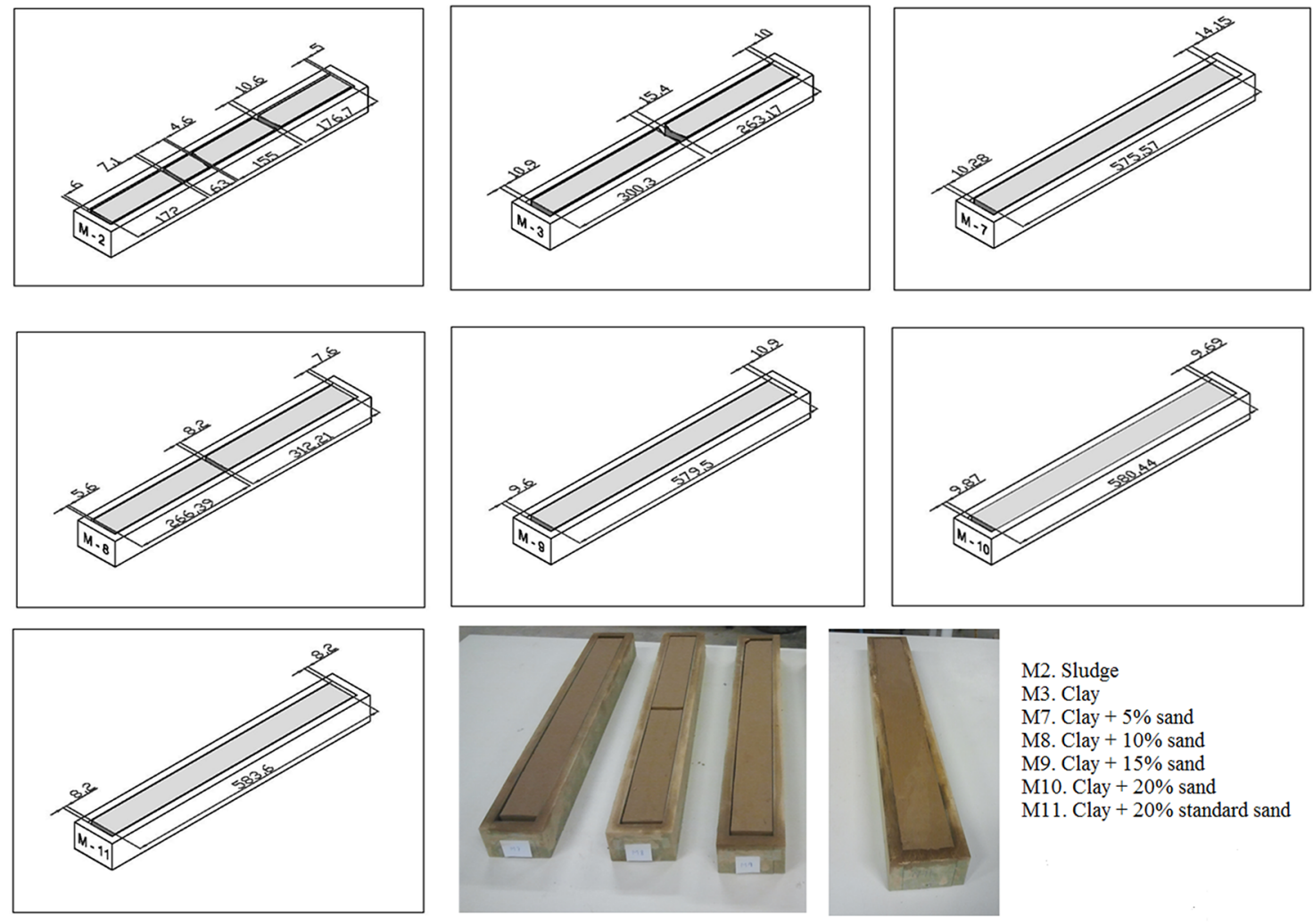

\section{M2. Sludge}

M7. Clay $+5 \%$ sand

M8. Clay $+10 \%$ sand

M9. Clay $+15 \%$ sand

M10. Clay $+20 \%$ sand

M11. Clay $+20 \%$ standard sand

FIGURE 7. Dry retraction test

that only had clay. The difference was substantial, reaching $30.6 \%$, well above the mentioned $15-20 \%$ (3), or what Spanish standards recommend: $12 \%$ in exposed fired clay and 16\% in covered fired clay. Nonetheless, the specimen with least water absorption was $\mathrm{C} 1(19 \%)$ in which the clay/ 

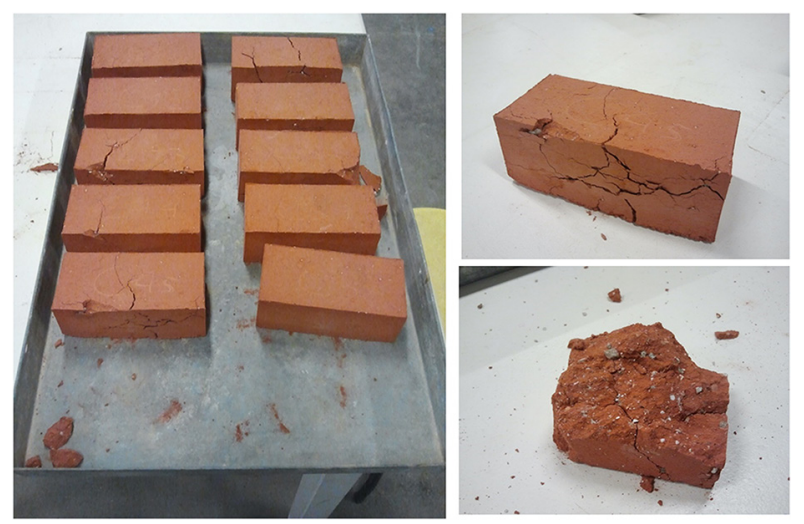

FIGURE 8. Effect of lime nodules in samples the greater the absorption. The specimen with the lowest capillary absorption rate was C1 with a 90/10 clay/sludge ratio. The reduction in capillary absorption reached $21.6 \%$. This rose to $54 \%$ if the sludgeonly specimen is compared to the specimen made entirely of clay (Table 9).

The compressive strength of the specimens also depended on the amount of sludge in the mixture. It can be said that the compressive strength of the specimens was enhanced with a proportion of up to $30 \%$ sludge. In this test, when measuring deformity, it was also observed that sludge yielded increased deformity. It was also possible to ascertain that, apart from two specimens made with non-standard sand, the use of standard sand

TABle 7. Density

\begin{tabular}{cccccccc}
\hline & \multicolumn{3}{c}{ Aparent density $\left(\mathrm{gr} / \mathrm{cm}^{3}\right)$} & & \multicolumn{2}{c}{ Real density $\left(\mathrm{gr} / \mathrm{cm}^{3}\right)$} \\
\cline { 2 - 3 } Sample & $\begin{array}{c}\text { Media } \\
\text { data }\end{array}$ & $\begin{array}{c}\text { Standard } \\
\text { deviation }\end{array}$ & $\begin{array}{c}\text { Standard relative deviation or } \\
\text { Coefficient of variation } \%\end{array}$ & $\begin{array}{c}\text { Media } \\
\text { data }\end{array}$ & & $\begin{array}{c}\text { Standard } \\
\text { deviation }\end{array}$ & $\begin{array}{c}\text { Standard relative deviation or } \\
\text { Coefficient of variation } \%\end{array}$ \\
\hline C 1 & 1.579 & 0.135 & 8.75 & 1.682 & 0.027 & 1.63 \\
C 2 & 1.574 & 0.003 & 0.17 & 1.600 & 0.002 & 0.11 \\
C 3 & 1.633 & 0.014 & 0.88 & 1.659 & 0.020 & 1.21 \\
C 4 & 1.590 & 0.009 & 0.58 & 1.617 & 0.011 & 0.67 \\
C 5 & 1.551 & 0.021 & 1.36 & 1.586 & 0.018 & 1.13 \\
FC 2 & 1.385 & 0.005 & 0.36 & 1.435 & 0.011 & 0.75 \\
V 2 & 1.654 & 0.015 & 0.90 & 1.692 & 0.010 & 0.61 \\
\hline
\end{tabular}

TABLE 8. Water absorption

\begin{tabular}{lccc}
\hline & \multicolumn{3}{c}{ Water absorption } \\
\cline { 2 - 4 } Sample & Media data \% & Standard deviation & $\begin{array}{c}\text { Standard relative deviation } \\
\text { or Coefficient of variation \% }\end{array}$ \\
\hline C 1 & 19.49 & 0.0079 & 4.04 \\
C 2 & 22.75 & 0.0019 & 0.84 \\
C 3 & 20.39 & 0.0079 & 3.90 \\
C 4 & 22.00 & 0.0032 & 1.48 \\
C 5 & 22.94 & 0.0055 & 2.39 \\
FC 2 & 28.50 & 0.0029 & 1.01 \\
V 2 & 19.76 & 0.0045 & 2.29 \\
\hline
\end{tabular}

sludge ratio was 90/10, similar to water absorption demonstrated by Dondi (2), quoting Probst, for gravel washing sludge, and Blanco et al. (8). There was a difference of $0.7 \%$ compared to the one in which only clay had been used (Table 8 ).

The capillary absorption test was performed on both faces of a single specimen for each of the dosages. In this case, as expected, the results were very similar to those obtained for the water absorption test; the greater the amount of sludge in the mixture, increased compressive strength by around $15 \%$. All the specimens had a compressive strength greater than $5 \mathrm{~N} / \mathrm{mm}^{2}$ (Table 10, Figure 9), as recommended by DB-SE-F, section 4.6.2 (37) of the Spanish Technical Building Code, except the specimen in which sludge only was used. In addition, some specimens $(\mathrm{C} 1, \mathrm{C} 3, \mathrm{C} 4, \mathrm{~V}$ and $\mathrm{C} 2$, very close to that limit) would be suitable for use in loadbearing walls, since their compressive strength was greater than $10 \mathrm{~N} / \mathrm{mm}^{2}$. Nevertheless, it should not 
The exploitation of sludge from aggregate plants in the manufacture of porous fired clay bricks $\bullet 13$

TABLE 9. Capillary absorption

\begin{tabular}{lccc}
\hline & \multicolumn{3}{c}{$\mathbf{C w}\left(\mathbf{k g} /\left(\mathbf{m}^{2} \mathbf{x m i n}\right)\right)$} \\
\cline { 2 - 4 } Sample & Media data & Standard Deviation & $\begin{array}{c}\text { Standard relative deviation or } \\
\text { Coefficient of variation \% }\end{array}$ \\
\hline C 1 & 0.807 & 0.098 & $12.10 \%$ \\
C 2 & 0.847 & 0.028 & $3.26 \%$ \\
C 3 & 0.821 & 0.101 & $12.35 \%$ \\
C 4 & 0.705 & 0,000 & $0.00 \%$ \\
C 5 & 0.795 & 0.116 & $14.66 \%$ \\
FC 2 & 0.725 & 0.115 & $15.86 \%$ \\
V 2 & 0.846 & 0.105 & $12.39 \%$ \\
\hline
\end{tabular}

TABLE 10. Compressive strength

\begin{tabular}{lccc}
\hline & \multicolumn{3}{c}{ Compression resistance $\left(\mathbf{N} / \mathbf{m m}^{2}\right)$} \\
\cline { 2 - 4 } Sample & Media data & Standard deviation & $\begin{array}{c}\text { Standard relative deviation or } \\
\text { Variation rate } \%\end{array}$ \\
\hline C 1 & 12.34 & 0.000 & 0.00 \\
FC 1 & 3.75 & 0.061 & 1.62 \\
V 1 & 12.52 & 2.815 & 22.49 \\
C 1 & 19.49 & 2.469 & 12.67 \\
C 2 & 9.92 & 1.002 & 10.10 \\
C 3 & 16.25 & 0.595 & 3.67 \\
C 4 & 11.10 & 0.112 & 1.01 \\
C 5 & 9.85 & 0.039 & 0.40 \\
FC 2 & 3.53 & 0.674 & 19.11 \\
V 2 & 15.12 & 3.721 & 24.62 \\
\hline
\end{tabular}

Specimens fired to kiln at $1000^{\circ} \mathrm{C}$ before fracture induced by lime nodules Specimens fired to kiln at $1050^{\circ} \mathrm{C}$ Specimens fired to kiln at $1000^{\circ} \mathrm{C}$

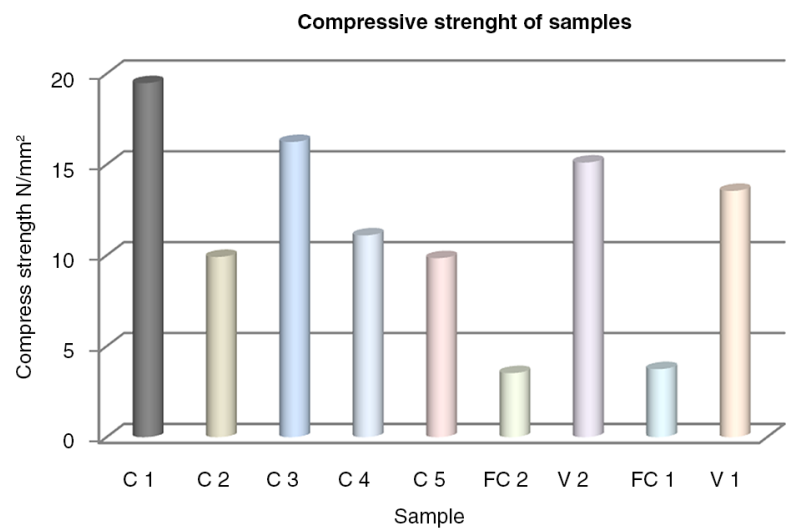

FIGURE 9. Media data of compressive strength

be forgotten that the standard specifies that the test must be performed on six specimens. The results should, therefore, be contemplated with the relativity that this entails.
In specimens of the same type in which compressive strength could be compared according to firing temperature, this was seen to increase by around $43 \%$ in specimen $\mathrm{C} 1$ (only one specimen was tested). Although further tests should be carried out with other specimens, this result - a significant increase - indicates that the compressive strength of specimens fired at $1050{ }^{\circ} \mathrm{C}$ may be increased. Muñoz et al. (6) analysing approximately 45 papers on waste use in fired clay bricks conclude that compressive strength is higher when the temperature is between 1000 and $1100^{\circ} \mathrm{C}$ than when the temperature is between 900 and $950{ }^{\circ} \mathrm{C}$, when the amount of sludge was almost less than $18 \%$. When inorganic waste was used, the difference of strength in both temperatures was significant when the percentage of waste is over $20 \%$. On the other hand, the compressive strength of those specimens made entirely of sludge or clay decreased by about $35 \%$ in the ones made of sludge only and by around $10 \%$ in those made of clay only (Figure 10 and Figure 11). 


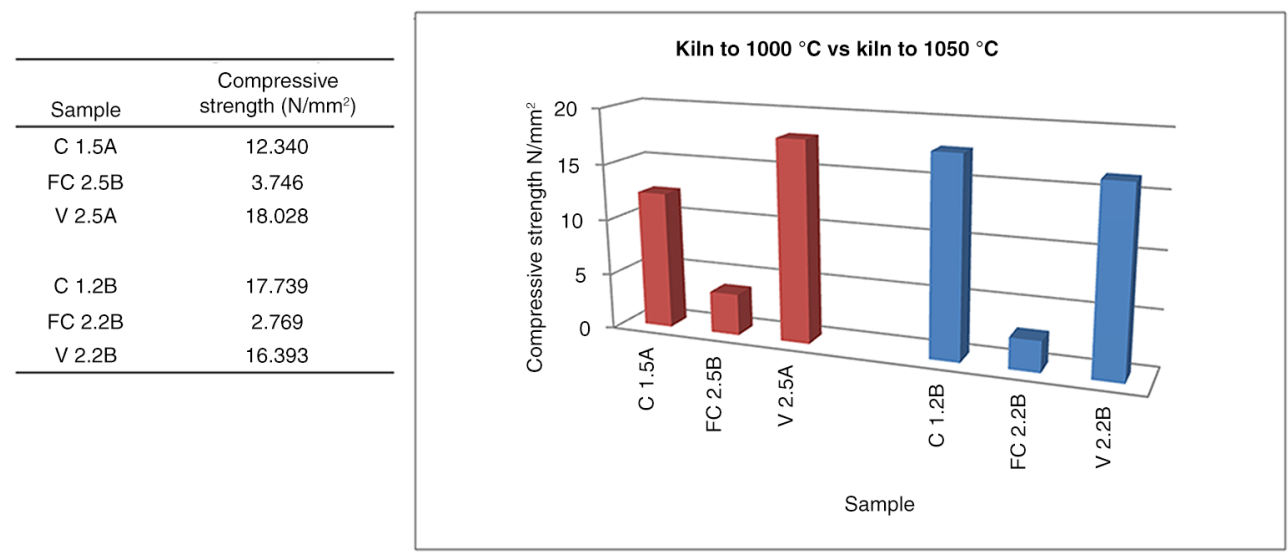

Figure 10. Comparison of samples fired to 1000 and $1050{ }^{\circ} \mathrm{C}$

\begin{tabular}{ccc}
\hline Sample & $1000^{\circ} \mathrm{C}$ & $1050^{\circ} \mathrm{C}$ \\
\hline C 1 & & 19.485 \\
C 2 & & 9.921 \\
C 3 & & 16.245 \\
C 4 & & 11.104 \\
C 5 & 9.853 & \\
FC 2 & 3.525 & \\
V2 & 15.115 & \\
FC 1 & 3.745 & \\
V1 & 13.553 & \\
\hline
\end{tabular}

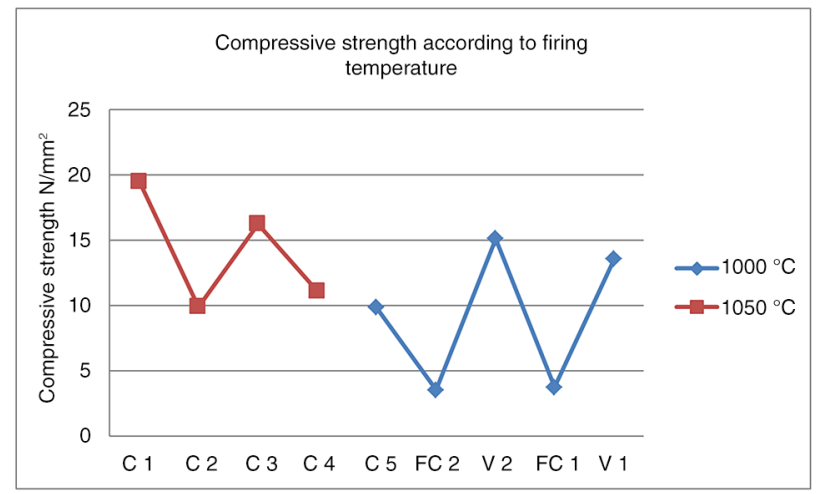

Figure 11. Compressive strength of different samples fired to 1000 and $1050{ }^{\circ} \mathrm{C}$

The wet-frost-dry test was performed based on the method recommended by Dr. Gabriel Barbeta (17), using the American ASTM and NLT standards together with the Spanish UNE standard. The test designed for the purpose of this study consisted of submerging the specimens in water for 24 hours and drying them in a drying oven for a further 24 hours at $80^{\circ} \mathrm{C}$. They were then removed and the 6 sides were brushed with a brush whose diameter was $50 \%$ of the surface of the sides of the specimen, applying a constant brushing pressure of $15 \mathrm{~N}$. Once brushed, they were weighed and placed in a freezer at $-15^{\circ} \mathrm{C}$ for 8 hours and dried in a drying oven at $80^{\circ} \mathrm{C}$ for a further 8 hours. All the sides were brushed again as previously mentioned and weighed again. The next step was to submerge them in salt water for 8 hours, place them in a freezer for 8 hours at $-15^{\circ} \mathrm{C}$, and in a drying oven at $80^{\circ} \mathrm{C}$ for 8 hours. Finally, the brushing process was repeated. With this process, we were able to determine the loss of weight of the different specimens. It was observed that the general tendency was that the larger the proportion of sludge in the sample, the greater the weight loss and, therefore, the less durability (Tables 11, Figure 12). Consequently, it was not possible to use specimens made only with sludge as they lose around $23 \%$ of their weight. The C2 specimens, made with $80 \%$ clay and $20 \%$ sludge, behaved differently, so a more thorough analysis should be carried out to determine the reason for their behaviour. The specimens presenting greater durability were the $\mathrm{Cl}$ ones, made up of $90 \%$ clay and $10 \%$ sludge.

The thermal conductivity value of the reference specimen was, using the first method, $1.74 \mathrm{~W} / \mathrm{m} . \mathrm{K}$, which differs considerably from the value of between 0.29 and $0.30 \mathrm{~W} / \mathrm{m} . \mathrm{K}$ for the brick supplied by the manufacturer. The Catalogue of Building Elements of the Spanish Technical Building Code (30) establishes a thermal conductivity value of between 0.29 and $0.90 \mathrm{~W} / \mathrm{mK}$ for baked clay. All the results exceeded these values (Figure 13). Thus, if we focus on the $\lambda$ value, the results of our specimens are wrong. However, if we observe the results of our specimens compared to the reference specimen, thermal conductivity can be seen to increase when sludge is added to the sample. The test should have been conducted using poly (methyl methacrylate), since the thermal conductivity value of porous fired clay bricks is below 1 . 
TABLE 11. Test wet-frost-dry

\begin{tabular}{|c|c|c|c|c|c|c|c|c|c|}
\hline \multirow[b]{3}{*}{ Sample } & \multicolumn{8}{|c|}{ Lost of weigth (gr) } & \\
\hline & \multicolumn{3}{|c|}{ 1st Cycle } & \multicolumn{3}{|c|}{ 2nd Cycle2 } & \multicolumn{3}{|c|}{ 3rd Cycle } \\
\hline & Media data & $\begin{array}{l}\text { Standard } \\
\text { deviation }\end{array}$ & $\begin{array}{c}\text { Standard } \\
\text { relative } \\
\text { deviation or } \\
\text { Variation } \\
\text { index \% }\end{array}$ & Media data & $\begin{array}{l}\text { Standard } \\
\text { deviation }\end{array}$ & $\begin{array}{c}\text { Standard } \\
\text { relative } \\
\text { deviation or } \\
\text { Variation } \\
\text { index \% }\end{array}$ & Media data & $\begin{array}{l}\text { Standard } \\
\text { deviation }\end{array}$ & $\begin{array}{c}\text { Standard } \\
\text { relative } \\
\text { deviation or } \\
\text { Variation } \\
\text { index \% }\end{array}$ \\
\hline $\mathrm{C} 1$ & 0.093 & 0.048 & 51.59 & 0.293 & 0.150 & 51.16 & -14.811 & 0.426 & 2.88 \\
\hline $\mathrm{C} 2$ & 0.247 & 0.081 & 32.82 & 0.805 & 0.215 & 26.67 & -16.598 & 0.251 & 1.51 \\
\hline C 3 & 0.168 & 0.107 & 63.27 & 0.455 & 0.120 & 26.36 & -15.360 & 0.302 & 1.97 \\
\hline $\mathrm{C} 4$ & 0.355 & 0.053 & 14.79 & 0.676 & 0.089 & 13.09 & -16.282 & 0.239 & 1.47 \\
\hline C 5 & 0.250 & 0.187 & 74.71 & 1.165 & 0.147 & 12.64 & -16.861 & 0.395 & 2.34 \\
\hline FC 2 & 8.381 & 2.373 & 28.31 & 18.441 & 2.255 & 12.23 & 0.732 & 3.019 & 412.50 \\
\hline $\mathrm{V} 2$ & 0.335 & 0.028 & 8.47 & 0.439 & 0.029 & 6.55 & -15.266 & 0.391 & 2.56 \\
\hline
\end{tabular}

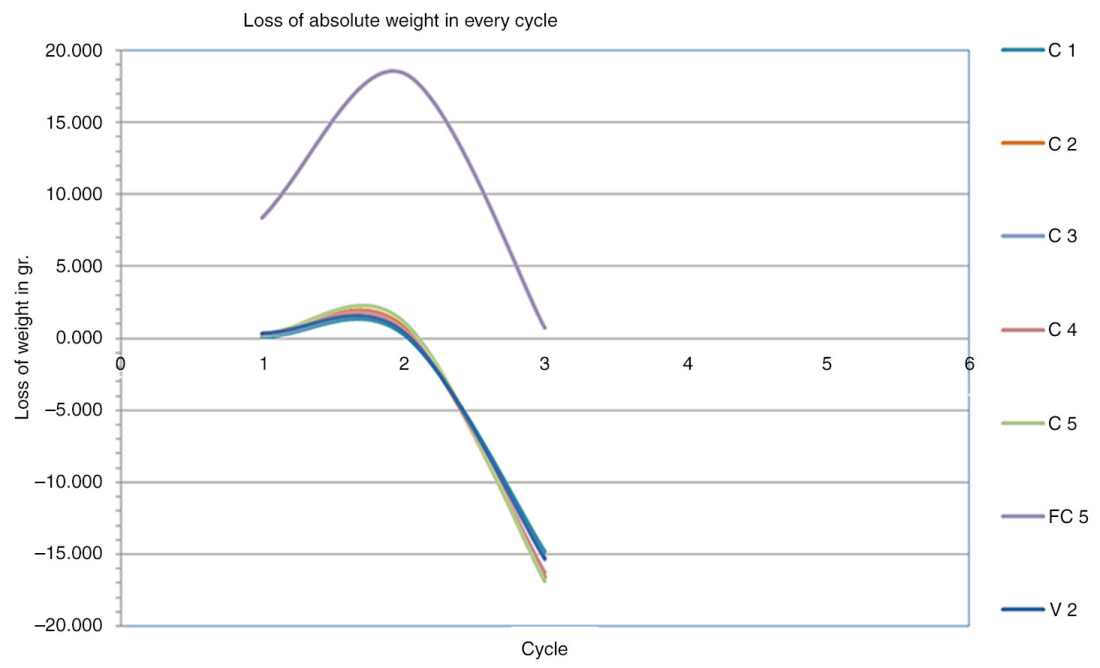

Figure 12. Loss of weight

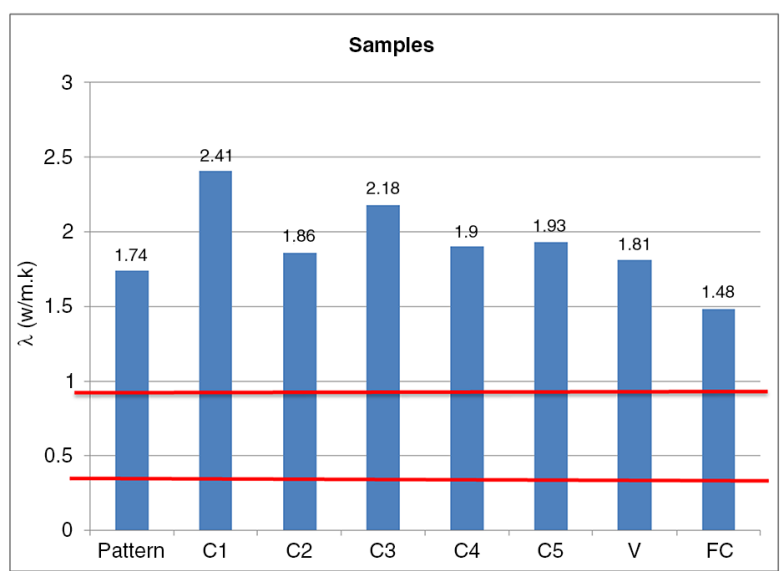

FIGURE 13. Thermal conductivity using hot plate method
As a satisfactory result was not obtained with the previously mentioned equipment, we decided to repeat the test in a custom-made calibrated thermal box, following the Spanish UNE-EN ISO 8990:1997 standard (29). The results for thermal conductivity were between 0.90 and 0.29 , as laid down by the Catalogue of Building Elements of the Spanish Technical Building Code (30) for fired clay (Table 12). Moreover, all the results approached those obtained by the reference sample (M4). Figure 11 shows the summary of all the results. The highest thermal conductivity value occurred in samples containing a greater proportion of clay. The use of standard sand led to an increase in the thermal conductivity coefficient (FC2 and V2). In specimens in which a mixture of sludge and clay had been used, we observed that in mixtures with less than $60 \%$ clay (sample C5), 
TABLE 12. Thermal conductivity using thermal box method

\begin{tabular}{lcl}
\hline Code & $\lambda$ & \multicolumn{1}{c}{ Composició } \\
\hline C 1 & 0.41 & $90 \%$ clay $+10 \%$ sludge $+20 \%$ standard sand $+10.7 \%$ water \\
C 2 & 0.55 & $80 \%$ clay $+20 \%$ sludge $+20 \%$ standard sand $+10.7 \%$ water \\
C 3 & 0.54 & $70 \%$ clay $+30 \%$ sludge $+20 \%$ standard sand $+10.7 \%$ water \\
C 4 & 0.55 & $60 \%$ clay $+40 \%$ sludge $+20 \%$ standard sand $+10.7 \%$ water \\
C 5 & 0.43 & $50 \%$ clay $+50 \%$ sludge $+20 \%$ standard sand $+10.7 \%$ water \\
FC 1 & 0.38 & $100 \%$ sludge $+20 \%$ sand from aggregate plant $+10.7 \%$ water \\
FC 2 & 0.47 & $100 \%$ sludge $+20 \%$ standard sand $+10.7 \%$ water \\
V 1 & 0.61 & $100 \%$ clay $+20 \%$ sand from aggregate plant $+10.7 \%$ water \\
V 2 & 0.66 & $100 \%$ clay $+20 \%$ standard sand $+10.7 \%$ water \\
\hline
\end{tabular}
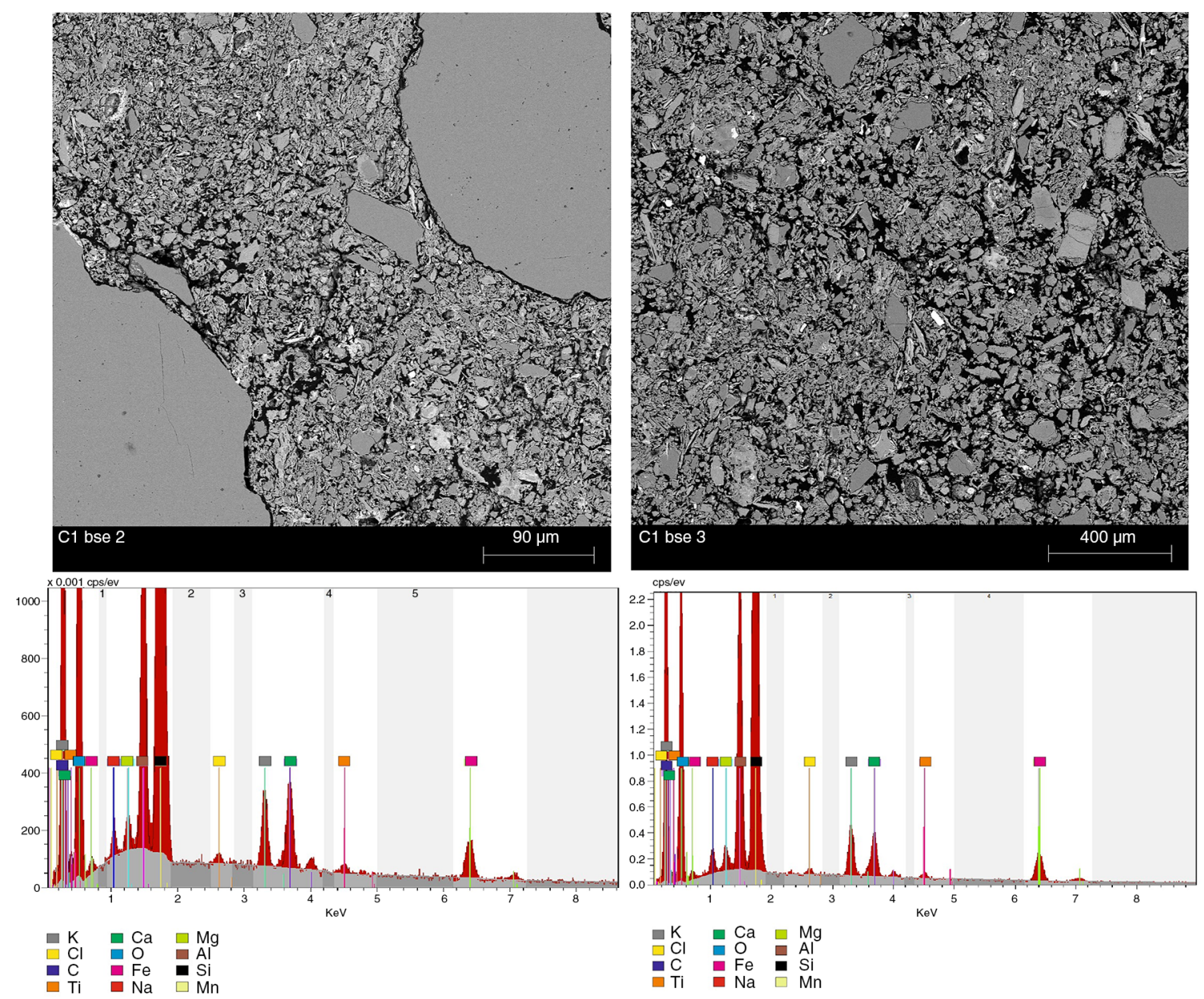

Figure 14a. SEM image and analysis of samples C1 and C2

the thermal conductivity coefficient was reduced by approximately $22 \%$. The addition of sludge increased the porosity of specimens and for this reason thermal conductivity decreased. The addition of standard sand produced a contrary effect as it reduced the porosity of specimens.
SEM analysis helps to confirm the results of other properties of these porous ceramic specimens. Comparing the effect of the addition of sludge on porous ceramic, two samples were analysed. Sample C1 and sample $\mathrm{C} 2$ were chosen, because $\mathrm{C} 2$ had double the amount of sludge than $\mathrm{Cl}$. The results were significant; 

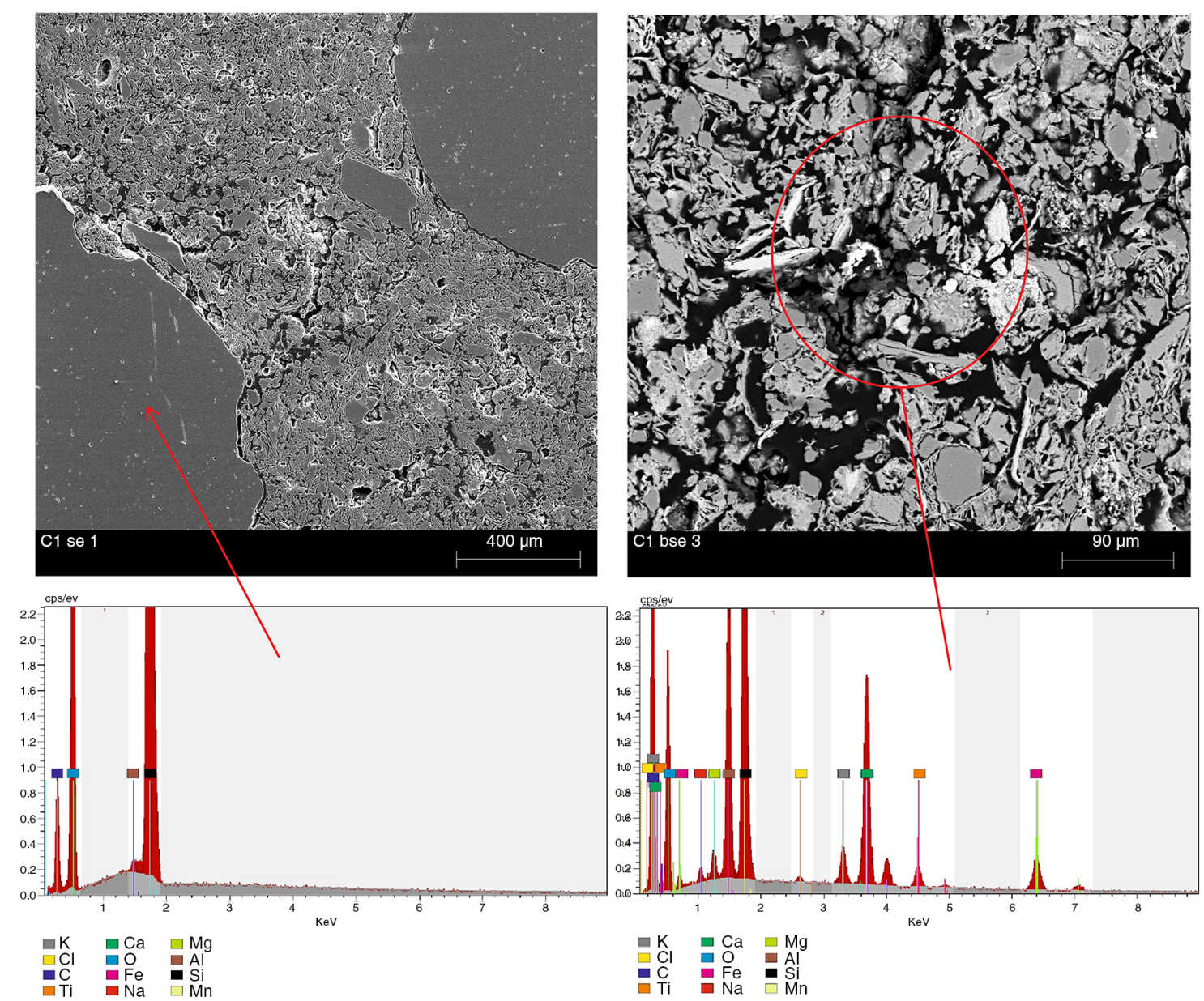

FIgURE 14b. SEM image and analysis of samples C1 se 1 (phyllosilicates) and $\mathrm{C} 1$ bse 3 (matrix)

the volume of pores increased in the $\mathrm{C} 2$ sample and the amount of phyllosilicates decreased (Figures 14a, 14b and $14 \mathrm{c}$ ). The second parameter should be considered relatively as two large grains of quartz appeared in the SEM analysis (Figure 14a). In spite of this, the amount of quartz in $\mathrm{C} 1(78 \%)$ was higher than in $\mathrm{C} 2(58 \%)$. In sample $\mathrm{C} 2$, a metallic element (in this case titanium) was detected. This was one the components that appeared in the XRD of sludge and also in clay (Figure 14c). Therefore, the addition of sludge increased porosity, reduced the specimen density and, in consequence, decreased compressive strength.

\section{CONCLUSIONS}

The first, and in our opinion, main conclusion is that the use of sludge at a rate of between 10 and $20 \%$ of the mass - samples C1 and C 2 -was the best option to make porous fired clay bricks with good properties for use as a building material. $\mathrm{C} 1$ had the lowest percentage of water absorption $(19.49 \%)$, one of the lowest percentages of capillarity absorption $(0.81 \%)$, high compression strength $(19.49 \mathrm{MPa})$, thermal conductivity in relation to density similar to standards $\left(1580 \mathrm{~kg} / \mathrm{m}^{3}-0.55 \mathrm{~W} / \mathrm{m} . \mathrm{K}\right)$, and a very low weight loss, which ensures durability. As a rule, analysing standard deviation and, specially, the coefficient of variation (below 20\%) the results were correct. Nevertheless, further tests need to be carried out on more specimens to establish more accurately the exact percentage of sludge needed.

According to this study, the addition of a large quantity of sludge increases porosity, water absorption, capillarity absorption and reduces compression strength and thermal conductivity. All the properties hinge on the volume of the pores.

The importance of using standard sand, or sand with a low level of carbonates, was verified, as this prevented problems such as lime nodules. Moreover, the use of standard sand increased the compressive strength of porous fired clay specimens by $15 \%$. All the specimens reached a degree of compressive strength (some were at the limit) that made them ideal for use in load-bearing walls $\left(10 \mathrm{~N} / \mathrm{mm}^{2}\right)$. In order to confirm this conclusion more tests will need to be done, since only two specimens of each type were analysed. 

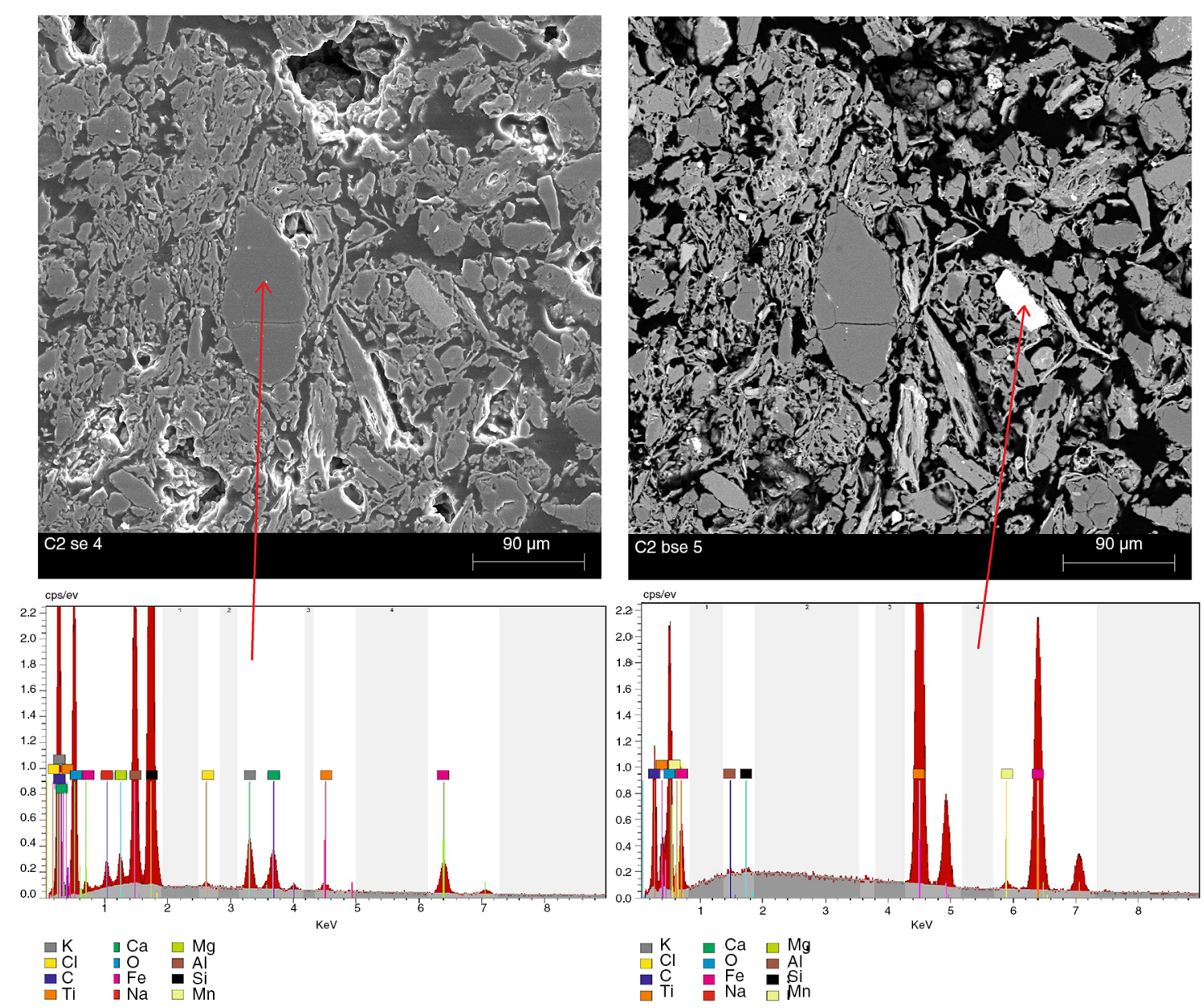

FIGURE 14c. SEM image and analysis of samples C2 se 4 (phyllosilicates) and C2 bse 5 (matrix)

On the other hand, with the results obtained it has been impossible to highlight if the firing temperature plays an important role in the behaviour of porous fired clay bricks insofar as compression strength is concerned, as those fired at $1050{ }^{\circ} \mathrm{C}$ (only one specimen) had greater compression strength, about $45 \%$, compared to those fired at $1000{ }^{\circ} \mathrm{C}$.

According to the thermal conductivity test, the use of a thermal chamber - even if it was made rudimentarily-assured good results compared to the standards. Nonetheless, evaluating the lowest temperature in the chamber to guarantee the right results may be implemented. Furthermore, the test results were wrong when using a hot plate due to the fact that polystyrene instead of poly (methyl methacrylate) was used.

It is extremely difficult to compare our results with the literature since researchers use a wide variety of wastes, different shaping processes to make the specimens, different specimen sizes, different firing temperatures, different standards and different tests. Dondi (2) quoting Bowman and Probst, demonstrated the properties of two kinds of fired clay bricks made from gravel and sand washing sludge. Compared to the sludge used in this study, it could be seen that the chemical composition of these waste materials is completely different. The amounts of different chemical elements are in some cases nearer the Probst product and, in others, nearer the Bowman product. The same occurs with the technological properties, certainly in the manufacturing process of specimens. The compressive strength of specimens made by extrusion - up to $80 \mathrm{MPa}$ - (2) cannot be compared to our hand-pressed specimens - 20 MPa.

In a first approximation, therefore and in the absence of a more thorough testing campaign, we can assert that the use of sludge from aggregate plants can be used in the manufacture of porous fired clay bricks. Using this mud will enable us to save on the raw starting materials. As we have seen in the grain size analysis test, part of the sludge replaces the sand fraction. At the same time its use provides an outlet for a waste product, thereby reducing the environmental impact that this produces. 


\section{ACKNOWLEDGEMENTS}

The collaboration agreement with the aggregate plant, Arids Guixeras S.L., leading to the analysis of the chemical composition of the sludge produced at this plant, has been fundamental for carrying out this study. We wish to highlight that once the agreement had come to an end, no obstacle was put in our way to continue using the sludge generated at this plant to further our research. We would also like to thank Argiles Colades S.A. for their generous collaboration in facilitating the clay used to make the specimens. The collaboration of Dr. Judit Molera is also gratefully acknowledged.

\section{REFERENCES}

1. Dondi, M.; Marsigli, M.; Fabbri, B. (1997) Recycling and industrial and urban wastes in brick production - A review. Tile \& Brick International 13 [3], 218-225.

2. Dondi, M.; Marsigli, M.; Fabbri, B. (1997) Recycling and industrial and urban wastes in brick production - A review (Part 2). Tile \& Brick International 13 [4], 302-309.

3. Raut, S.P.; Ralegaonkar, R.V.; Mandavgane, S.A. (2011) Development of sustainable construction material using industrial and agricultural solid waste: A review of wastecreate bricks. Construc. Build. Mat. 25, 4037-4042. http:// dx.doi.org/10.1016/j.conbuildmat.2011.04.038.

4. Aeslina, A.; Mohajerani, A. (2011) Bricks: an excellent Building material for recycling wastes-A review. Proceedings of the last International Conference Environmental Management and Engineering. 2011 Calgary, AB, Canada, 108-115. http://dx.doi.org/10.2316/P.2011.736-029.

5. Zhang, L. (2013) Production of bricks from waste materials - A review. Construc. Build. Mat. 47, 643-655. http:// dx.doi.org/10.1016/j.conbuildmat.2013.05.043.

6. Muñoz, P.; Morales, M.P.; Mendivil, M.A.; Muñoz, L. (2014) Fired clay bricks manufactured by adding waste as a sustainable construction material - A review. Construc. Build. Mat. 63, 97-107. http://dx.doi.org/10.1016/j. conbuildmat.2014.03.045.

7. Monteiro, S.N.; Fontes, C.M. (2014) On the production of fired clay bricks from waste materials: A critical update. Construc. Build. Mat. 68, 599-610. http://dx.doi. org/10.1016/j.conbuildmat.2014.07.006

8. Blanco, I.; Rodas. M.; Sánchez, C.J. (2000) Caracterización mineralogica y aplicacions cerámicas de los lodos procedentes del lavado de áridos naturales. Cadernos Laboratorio Xeolóxico de Laxe 25, 377-380.

9. Oliver, I. (2002) Estudi de l'aprofitament de subproductes industrials procedents del tractament d'àrids com a matèria primera ceràmica, Universidad Politécnica de Cataluña, Departamento de Ingeniería del Terrano, Cartografia y Geofisica (minor thesis). http://dx.doi.org/2099.1/6209

10. Galán-Arboleas, R.J.; Merino, A.; Bueno, S. (2013) Utilización de las nuevas materias primas y residuos industriales para mejorar las posibilidades del uso de los materiales cerámicos del área de Bailén (Jaén). Mater. Construcc. 63 [312], 553-568. http://dx.doi.org/10.3989/mc.2012.03412.

11. Costafreda, J.L. (2008) Geología, caracterización y aplicaciones de las rocas zeolíticas del complejo volcánico de Cabo de Gata (Almería).Universidad Politécnica de Madrid, Escuela Técnica Superior de Ingenieros de Minas (doctoral thesis). http://dx.doi.org/10803/20386.

12. UNE 103102:1995. Grain size analysis of fine soils by sedimentation. Densimetric method, AENOR, Spain based on ASTM D-422-63 (2007)e2. Standard test method for particle-size analysis of soils, ASTM International. http:// dx.doi.org/10.1520/D0422-63R07E02.

13. UNE 103103:1994. Determination of liquid limit of soil using Casagrande method, AENOR, Spain.
14. UNE 103104:1993. Determination of plastic limit of soil, AENOR, Spain.

15. UNE 103108:1996. Determination of shrinkage characteristics of soil, AENOR, Spain.

16. ASTM 427-04 (2008) Test method for shrinkage factors of soils by the mercury method, ASTM International. http:// dx.doi.org/10.1520/D0427-04.

17. Barbeta, G. (2002) Mejora de la tierra estabilizada en el desarrollo de una arquitectura sostenible hacia el siglo XXI, Universidad Politécnica de Cataluña, Departamento de Construcciones Arquitectónicas I (doctoral thesis). http://dx.doi.org/10803/6106.

18. UNE 103301:1994. Determination of soil density. Hydrostatic balance method, AENOR, Spain.

19. UNE 103105:1993. Determination of minimum sand density, AENOR, Spain.

20. UNE-EN 77221:2011. Test methods for brick masonry. Part 21: Determination of water absorption for fired clay and silica calcareous brick masonry by cold water absorption, AENOR, Spain

21. UNE-EN 72211:2011. Test methods for brick masonry. Part 11: Determination of water absorption by capillarity for concrete masonry, autoclaved cellular concrete, artificial and natural stone, and initial rate of absorption of fired clay brick masonry, AENOR, Spain.

22. UNE-EN 7721:2011. Test Methods for brick masonry. Part 1: Determination of compressive strength, AENOR, Spain.

23. ASTM D559-03. Standard test methods for wetting and drying compacted soil-cement mixtures. http://dx.doi. org/10.1520/D0559-03.

24. ASTM D560-03. Standard test methods for freezing and thawing compacted soil-cement mixtures, ASTM International. http://dx.doi.org/10.1520/D0560-03.

25. NLT-303/72. Freeze-thaw performance of soil-cement specimens, CEDEX, Spain.

26. UNE 7033:1951. Freeze and permeability tests for tile and cement floor tiles, AENOR, Spain and UNE 67028:1997 EX. Fired clay ceramic bricks. Freeze test, AENOR, Spain.

27. Laaroussi, N.; Lauriat, G.; Garoum, M.; Cherki, A.; Jannot, Y. (2014) Measurement of thermal properties of brick materials based on clay mixtures. Construc. Build. Mat. 70, 351-361. http://dx.doi.org/10.1016/j.conbuildmat.2014.07.104.

28. Bal, H.; Jannot, Y: Gaye, S.; Demeurie, F. (2013) Measurement and modelisation of the thermal conductivity of a wet composite porous medium: laterite based bricks with millet waste additive. Construc. Build. Mat. 41, 586-593. http://dx.doi.org/10.1016/j.conbuildmat.2012.12.032.

29. UNE-EN ISO 8990:1997; Determination of thermal transmission properties in a stable system. Hot box and calibration methods, AENOR, Spain.

30. CTE (2010) Spanish Technical Building Code. Catalogue of Building Elements, Instituto Eduardo Torroja de la Construcción, Spain.

31. CTE. DA DB-HE/1 (2015) Spanish Technical Building Code. Supporting Document of the Basic Document, Saving Power/1. Ministerio de Fomento, Spain.

32. Stoch, L.; Sikora, W. (1976) Transformations of micas in the process of kaolinitization of granites and gneisses. Clays and Clay Minerals 24, 156-162

33. Swapan, Kr.D.; Kausik, D. (2003) Differences in densification behaviour of $\mathrm{K}$-and Na-Feldspar-containing porcelain bodies. Thermochimica Acta 406, 199-206. http://dx.doi. org/10.1016/S0040-6031(03)00257-0.

34. Boussak, H.' Chemani, H. Serier A. (2015) Characterization of porcelain tableware formulation containing bentonite clay. Int. J. Physic. Sci. 10, 38-45. http://dx.doi.org/10.5897/ IJPS2014.4218.

35. Faust, G.T. (1950) Thermal analysis studies on carbonates. I. Aragonite and calcite. American Mineralogist 35, 207-224.

36. Vázquez, M.; Jiménez-Millán, J. (2004) Materias primas ricas en arcilla de las Capas Rojas Triásicas (Norte de Jaén, España) para fabricar materiales de construcción. Mater. Construcc. 54 [273], 5-20. http://dx.doi.org/10.3989/mc.2004.v54.i273.219

37. CTE. DB-SE-F (2009) Spanish Technical Building Code. Basic document on structural safety and masonry, Ministerio de Fomento, Spain. 